\title{
AN ASSESSMENT OF ENERGY AND ENVIRONMENTAL ISSUES RELATED TO THE USE OF GAS-TO-LIQUID FUELS IN TRANSPORTATION
}

\author{
David L. Greene \\ Center for Transportation Analysis \\ Oak Ridge National Laboratory
}

November 1999

\section{Prepared by the \\ OAK RIDGE NATIONAL LABORATORY}

Oak Ridge, Tennessee 37831 managed by

\section{LOCKHEED MARTIN ENERGY RESEARCH CORP.}

for the

U. S. DEPARTMENT OF ENERGY

under contract DE-AC05-96OR22464

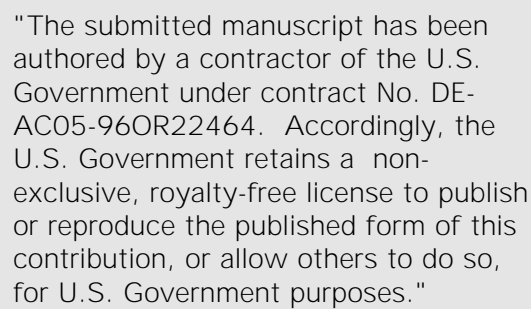

"The submitted manuscript has been authored by a contractor of the U.S. Government under contract No. DEAC05-960R22464. Accordingly, the U.S. Government retains a nonexclusive, royalty-free license to publish or reproduce the published form of this contribution, or allow others to do so, for U.S. Government purposes." 


\section{TABLE OF CONTENTS}

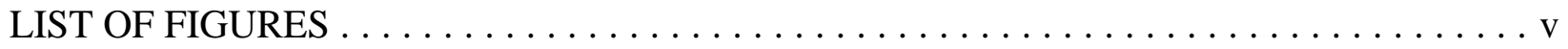

LIST OF TABLES $\ldots \ldots \ldots \ldots \ldots \ldots \ldots \ldots \ldots \ldots \ldots \ldots \ldots \ldots \ldots$

ACKNOWLEDGMENTS $\ldots \ldots \ldots \ldots \ldots \ldots \ldots \ldots \ldots \ldots \ldots \ldots \ldots \ldots \ldots$ vii

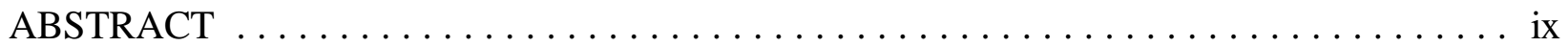

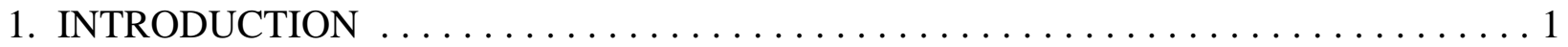

2. GAS-TO-LIQUIDS TECHNOLOGY OVERVIEW $\ldots \ldots \ldots \ldots \ldots \ldots \ldots \ldots \ldots \ldots \ldots 7$

3. POTENTIAL FEEDSTOCK RESOURCES $\ldots \ldots \ldots \ldots \ldots \ldots \ldots \ldots \ldots \ldots$

4. DETERMINANTS OF PRODUCTION COSTS AND WORLD SUPPLY $\ldots \ldots \ldots \ldots$

5. EMISSIONS BENEFITS OF NEAT AND BLENDED GTL FUELS . . . . . . . . . . . 19

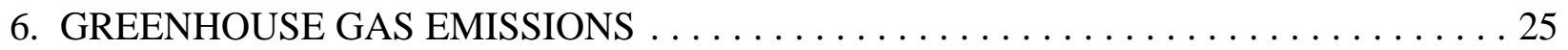

7. DISTRIBUTION OF WORLD RESOURCES AND IMPLICATIONS FOR

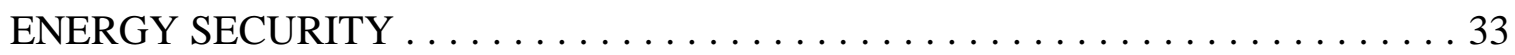

8. WORLD OIL MARKETS AND IMPLICATIONS FOR ENERGY SECURITY . . . . . . 41

8.1 THE OPEC CARTEL AS IMPERFECT PARTIAL MONOPOLIST . . . . . . . . 42

8.2 ENERGY SECURITY IMPACTS OF G-T-L: A SIMULATION . . . . . . . . . 44

9. CRITICAL ISSUES IN THE FUTURE OF G-T-L'S $\ldots \ldots \ldots \ldots \ldots \ldots \ldots \ldots \ldots \ldots$

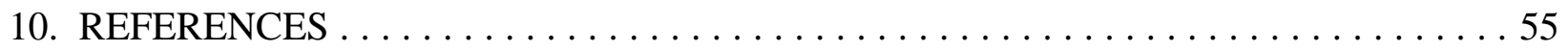

APPENDIX: VON STACKELBERG THEORY FOR SUBSTITUTE GOODS $\ldots \ldots \ldots \ldots 1$ 


\section{LIST OF FIGURES}

Figure 1. Gasoline Blending Components v. Alternative Fuels as Sources of Non-Petroleum

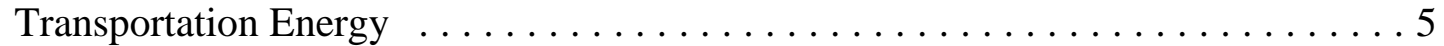

Figure 2. GREET Model Pollutant Emissions Estimates for Passenger Cars . . . . . . . . . . . 24

Figure 3. Distribution of Ultimate Resources of Oil and Gas within OPEC, 1993 . . . . . . 29

Figure 4. Concentration of Energy Resources in OPEC, 1993 .................... 35

Figure 5. Distribution of World's Estimated 5,241 TCF of Stranded Gas Resources . . . . . . 35

Figure 6. Estimated Distribution of Gas Resources by Field Size in TCT . . . . . . . . 36

Figure 7. Worldwide Venting, Flaring and Re-injection of Natural Gas $\ldots \ldots \ldots \ldots . \ldots 37$

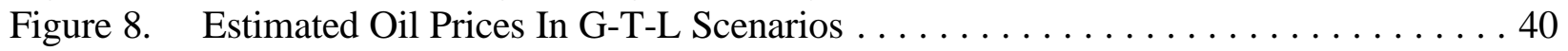

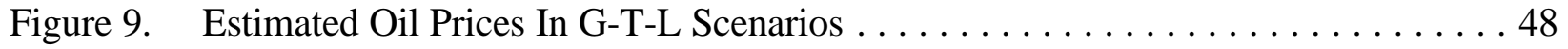

\section{LIST OF TABLES}

Table 1. Assumptions for Corke's Estimates of G-T-L Production Costs $\ldots \ldots \ldots \ldots \ldots \ldots$

Table 2. Approximate Properties of Three Diesel Fuels . . . . . . . . . . . . . . . . . . . 19

Table 3. Percent Reductions in Emissions in Recent Comparative Studies

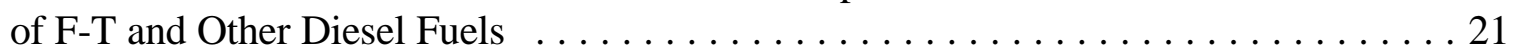

Table 4. Potential Benefits of F-T Fuels for Emissions Control via Fuel Injection Strategies . . 23

Table 5. Diesel Fuel Carbon Content and Energy Equivalency ................... 26

Table 6. Upstream Emissions from the Production and Distribution of Various Diesel Fuels . . 27

Table 7. Energy Efficiency and Carbon Emissions for Motor Fuels, 2015 . . . . . . . . . . . 27

Table 8. GREET Model GHG Emissions Estimates $\ldots \ldots \ldots \ldots \ldots \ldots \ldots \ldots \ldots \ldots \ldots \ldots \ldots$

Table 9. Costs of Different $\mathrm{CO}_{2}$ Capture and Disposal Options $\ldots \ldots \ldots \ldots \ldots \ldots \ldots \ldots$

Table 10. Cost of Carbon Sequestration per Gallon of Fischer-Tropsch Product . . . . . . . . 31

Table 11. Summary of Resource Costs for Associated Gas . . . . . . . . . . . . . . . 38

Table 12. Gas-to-Liquids Simulation Model Results for Eight Scenarios . . . . . . . . . . . . 47

Table 13. Simulations of G-T-L Impacts on OPEC Revenues and Profits . . . . . . . . . . . . 49

Table 14. Simulation of G-T-L Impacts Combined with an Oil Supply Shock . . . . . . . . . . 49 


\section{ACKNOWLEDGMENTS}

The author gratefully acknowledges the support of the U.S. Department of Energy Office of Policy for this work, the advice and suggestions of Barry McNutt, Fred Abel, Jerry Hadder, Lew Fulton and Harry Vidas, and the assistance of Debbie Bain in preparing this report. The author, however, is solely responsible for any and all errors herein. This work is dedicated to Michael Greene. 


\begin{abstract}
Recent technological advances in processes for converting natural gas into liquid fuels, combined with a growing need for cleaner, low-sulfur distillate fuel to mitigate the environmental impacts of diesel engines have raised the possibility of a substantial global gas-to-liquids (G-T-L) industry. This report examines the implications of G-T-L supply for U.S. energy security and the environment. It appears that a G-T-L industry would increase competitiveness in world liquid fuels markets, even if OPEC states are major producers of G-T-L's. Cleaner G-T-L distillates would help reduce air pollution from diesel engines. Implications for greenhouse gas (GHG) emissions could be positive or negative, depending on the sources of natural gas, their alternative uses, and the degree of sequestration that can be achieved for $\mathrm{CO}_{2}$ emissions produced during the conversion process.
\end{abstract}




\section{AN ASSESSMENT OF ENERGY AND ENVIRONMENTAL ISSUES RELATED TO THE USE OF GAS-TO-LIQUID FUELS IN TRANSPORTATION}

\section{INTRODUCTION}

Since Fischer and Tropsch invented the process for converting hydrogen and carbon monoxide into liquid fuels in 1923, the world has had a feasible but not economical means to convert natural gas into transportation fuels. Two recent developments warrant a reconsideration of the importance of gas-to-liquids (G-T-L) conversion for world energy markets: (1) advances in catalysts and numerous other components of G-T-L technology have significantly reduced conversion costs, increased the selectivity with which the Fischer-Tropsch (F-T) process can produce middle distillates, and may have drastically reduced the scale at which G-T-L becomes economical; and (2) mounting pressure to reduce automotive emissions, especially from diesel vehicles, is almost certain to require dramatically cleaner distillate fuels, potentially creating a willingness to pay for premium quality distillate fuels and distillate fuel blendstocks such as can be produced by the F-T process. For these reasons, this paper will focus on the conversion of natural gas to distillate fuels for transportation.

The central issue explored in this paper is whether widespread use of natural gas to produce distillate fuels would result in more competitive world liquid fuels markets and thereby enhance energy security. Process improvements permitting reduced plant size would not only make G-T-L's more cost competitive with petroleum fuels, but would also greatly expand the potential resource base for G-T-L's to include numerous smaller gas fields that may have no other economical use. Because gas fields are less geographically concentrated than oil fields, this could increase competition in world liquid fuels markets and weaken the market power of the OPEC cartel. Because these fields might not otherwise be exploited, G-T-L technology could expand the energy resource base for transportation, thereby making a contribution to the sustainability of motorized transport. The potential to simultaneously cut vehicle emissions and improve energy security would make G-T-L fuels that much more attractive. There are legitimate questions, however, about whether liquids produced from natural gas would increase net emissions of greenhouse gases, especially carbon dioxide.

In order to increase U.S. energy security, section 502(b)(2) of the Energy Policy Act (EPACT) of 1992 (PL 102 486) suggested goals of displacing 10 percent of transportation fuel with nonpetroleum replacement fuels by the year 2000 and 30 percent by 2010. Replacement fuels include alternative fuels, which are defined by EPACT as:

“...methanol, denatured ethanol, and other alcohols: mixtures containing 85 percent or more (or such other percentage, but not less than 70 percent, as determined by the Secretary of Energy, by rule,...) by volume of methanol, denatured ethanol, and other alcohols with gasoline or other fuels; natural gas; 
liquefied petroleum gas; hydrogen; coal derived liquid fuels; fuels (other than alcohol derived from biological materials; electricity (including electricity from solar energy), and any other fuel the Secretary determines, by rule, is substantially not petroleum and would yield substantial energy security benefits and substantial environmental benefits."

Replacement fuels also include the portion of any motor fuel that is an alternative fuel, plus "...ethers, or any other fuel the Secretary of Energy determines, by rule, is substantially not petroleum and would yield substantial energy security benefits and substantial environmental benefits."

To date, replacement fuels have displaced far more petroleum than alternative fuels. According to Energy Information Administration estimates (U.S. DOE/EIA, 1997b, table 10), alternative fuels comprised 0.22 percent of highway motor fuel use in 1998, while replacement fuels, almost entirely ethers and ethanol blended with gasoline, comprised 2.4 percent. It can be argued that all natural gas liquids, as well as hydrogen produced from gas, should be considered replacement fuels. This would increase the replacement fuel share substantially. Middle distillates derived from natural gas and blended with conventional diesel fuel could be considered a replacement fuel, but only if the Secretary of Energy determines, by rule, that the fuel would yield substantial energy security benefits and substantial environmental benefits. A goal of this paper is to summarize what is currently known about these two issues with respect to middle distillates from natural gas.

The U.S. transportation sector's dependence on petroleum remains a source of environmental, economic, and strategic problems. Record high levels of petroleum imports and the enduring near-total dependence of the U.S. transportation system on oil for energy, sustain concerns about U.S. energy security. And while enormous progress has been made in reducing the tailpipe emissions from properly operating new motor vehicles, the continued growth of vehicle travel combined with emissions from other sources have made achieving national air quality standards a nagging problem for many metropolitan areas. With U.S. carbon dioxide emissions growing at 12 percent per year, and already more than 10 percent above 1990 levels, the Kyoto Protocol target of a 7 percent reduction in greenhouse gas (GHG) emissions over 1990 levels by 20082012 will not be easy to achieve. The transportation sector must curb its emissions if the national goal is to be met. Extensive use of liquid fuels from natural gas might be counterproductive or possibly helpful to this effort, depending on a number of factors. Finally, rising apprehensions about the sustainability of the growth of modern market economies leads to questions about their continued reliance on conventional fossil fuels. While there is no one simple solution to all these problems, the potential contribution of replacement fuels, alternative energy sources that can be blended with conventional petroleum fuels with little or no change in infrastructure, appears to have been neglected.

Does oil dependence still matter? When world oil prices recently hovered around $\$ 10$ per barrel, worries about U.S. energy security seemed like a distant memory. The sudden, near doubling of 
oil prices this year in response to disciplined adherence to production quotas by OPEC cartel members, assisted by other non-OPEC producers, seems to have dispelled the belief that OPEC is dead. Today the United States imports more than half of the petroleum its economy consumes, the highest levels on record (U.S. DOE/EIA, 1998a, table 1.8). Last year, U.S. expenditures on oil comprised about the same share of GDP as they did in 1972, the year preceding the first oil crisis. And the U.S. transportation sector, responsible for two-thirds of U.S. petroleum consumption (Davis, 1998, p. 1-1), remains 97 percent dependent on petroleum (U.S. DOE/EIA, 1998b, table 2.1). ${ }^{1}$ Furthermore, the basic distribution of world oil resources has not changed in any significant way (Masters et al., 1994). Some warn of an imminent peak in world oil production sometime between 2005 and 2020 (Campbell and Laherrère, 1998; Kerr, 1998), while others foresee continued availability of economical petroleum through at least the next half century (World Energy Council, 1995). Although the Energy Information Administration (U.S. DOE/EIA, 1998c, p. 25) generally foresees moderate oil prices and abundant supply through 2020, they acknowledge the possibility of temporary disruptions as a result of unforeseen political and economic circumstances and the concentration of world oil resources in a relatively few states.

World economic conditions, in particular the Asian economic crisis, clearly contributed to the 1999 collapse of world oil prices to near competitive market levels. Increased output from Iraq (from $0.6 \mathrm{mmbd}$ in 1996 to 2.0 for the first 8 months of this year) have also helped to push prices down. But if world oil markets have changed fundamentally since the 1970s and 1980s, it must be due to technological advances in oil exploration and production, and the efficiency of petroleum use. Breakthroughs such as 3-D seismic imaging to more precisely locate deposits before drilling, horizontal and "smart" drilling technologies to more efficiently exploit reserves, and offshore deepwater drilling technologies, have combined to enable the world's non-OPEC producers to find and produce oil more cheaply (Fagan, 1997; Salameh, 1995). While the longterm impacts of these technologies are unclear, they have undoubtedly increased the ability of rest-of-world (ROW) oil suppliers to respond to oil price changes, thereby weakening the market power of the OPEC cartel.

On the demand side, reducing oil dependence will depend on making efficiency improvements cheaper and easier and on creating low cost, high-performance substitutes for petroleum (Greene, 1997). Rapid improvements in motor vehicle fuel economy were made between 1975 and 1985. Since then, however, the average fuel economy of new passenger cars and light trucks has remained virtually constant. The average efficiency of passenger cars sold in 1988 was $28.8 \mathrm{mpg}$. New cars averaged $28.8 \mathrm{mpg}$ in 1998, as well. New light trucks averaged $21.3 \mathrm{mpg}$ in 1988 but only $20.8 \mathrm{mpg}$ this year. Alternative fuel use in the United States is growing, but slowly. Estimated use of natural gas, LPG, alcohols and electricity to power highway vehicles increased

\footnotetext{
${ }^{1}$ Because EIA statistics on transportation petroleum use count gasoline blending stocks as petroleum regardless of actual origin, they tend to overestimate petroleum's share of total transportation energy. Natural gas converted into MTBE and ethanol blended in gasohol probably account for approximately two percent of transportation energy (U.S. DOT/BTS, 1997, p. 92).
} 
from 230 thousand gasoline equivalent gallons (geg) in 1992 to an estimated 340 thousand geg in 1998 (U.S. DOE/EIA, 1997b, table 10). Yet with total U.S. highway gasoline consumption at 120 billion gallons per year, alternative fuel use is still a drop in the bucket.

Recent experience suggests that replacement fuels, non-petroleum liquid fuels that can be blended with conventional gasoline or diesel without changes in the fuel distribution infrastructure, are likely to be far more important than alternative fuels, at least in the near term. In 1997, nearly ten times more non-petroleum energy found its way into motor vehicles in the form of oxygenates blended with gasoline than all alternative fuels combined (U.S. DOT/BTS, 1997, p. 92). An estimated 2.84 billion geg of ethers and 0.85 billion geg of ethanol were blended with gasoline in 1998 to help meet air quality goals (U.S. DOE/EIA, 1997b, table 10). The combined total of 3.7 billion geg of oxygenates is an order of magnitude greater than all alternative fuel use. From 1992 to 1998, oxygenate use doubled. The driving force behind this rapid growth is the environmental regulations requiring oxygenated and reformulated gasoline (RFG) use in air quality nonattainment areas. From zero in 1993, RFG production increased to 29 billion gallons in 1995, one-fourth of total U.S. gasoline consumption.

To date, methy tertiary butyl ether (MTBE), derived primarily from natural gas, has accounted for nearly all of the ethers blended with gasoline. This is almost certain to change. A ban on MTBE by 2002 has been announced for California and a nationwide ban is likely to follow (Remote Gas Strategies, 1999d). MTBE has been detected in drinking water, apparently as a result of leaking storage tanks and spills.

Use of non-petroleum blending stocks expanded rapidly once fiscal subsidies or environmental mandates made them economical. The U.S. Bureau of Transportation Statistics reports that the non-petroleum energy content of gasoline increased from 0.2 percent in 1981 to 3.3 percent in 1995. From 1981 to 1985, increased use of ethanol to produce gasohol accounted for a doubling of non-petroleum transportation energy use (Figure 1). Demand for ethanol as a blending stock was driven by a 5.4 cents per gallon federal tax subsidy for gasohol. From 1990 to 1995, however, demand for MTBE to make reformulated gasoline was the driving force behind a quadrupling of non-petroleum blending stocks over that five year period. The speed with which non-petroleum blending stock use grew suggests that replacement fuels may have a role in increasing responsiveness to oil supply disruptions.

This white paper addresses five key issues: It (1) examines recent and anticipated future developments in G-T-L technology, (2) considers the resource base for G-T-L production and especially its size in relation to crude oil resources, (3) reviews the determinants of the cost of G-T-L's, (4) explores the key environmental issues surrounding G-T-Ls, and (5) presents a theoretical context for analyzing the impacts of G-T-L's on energy security and illustrates the possible impacts with an example. Four key issues emerge.

1. Can G-T-L's be a significant energy source at competitive prices?

2. Can G-T-L blends significantly reduce motor vehicle emissions? 


\section{Figure 1. Gasoline Blending Components v. Alternative Fuels As Sources of Non-Petroleum Transportation Energy}

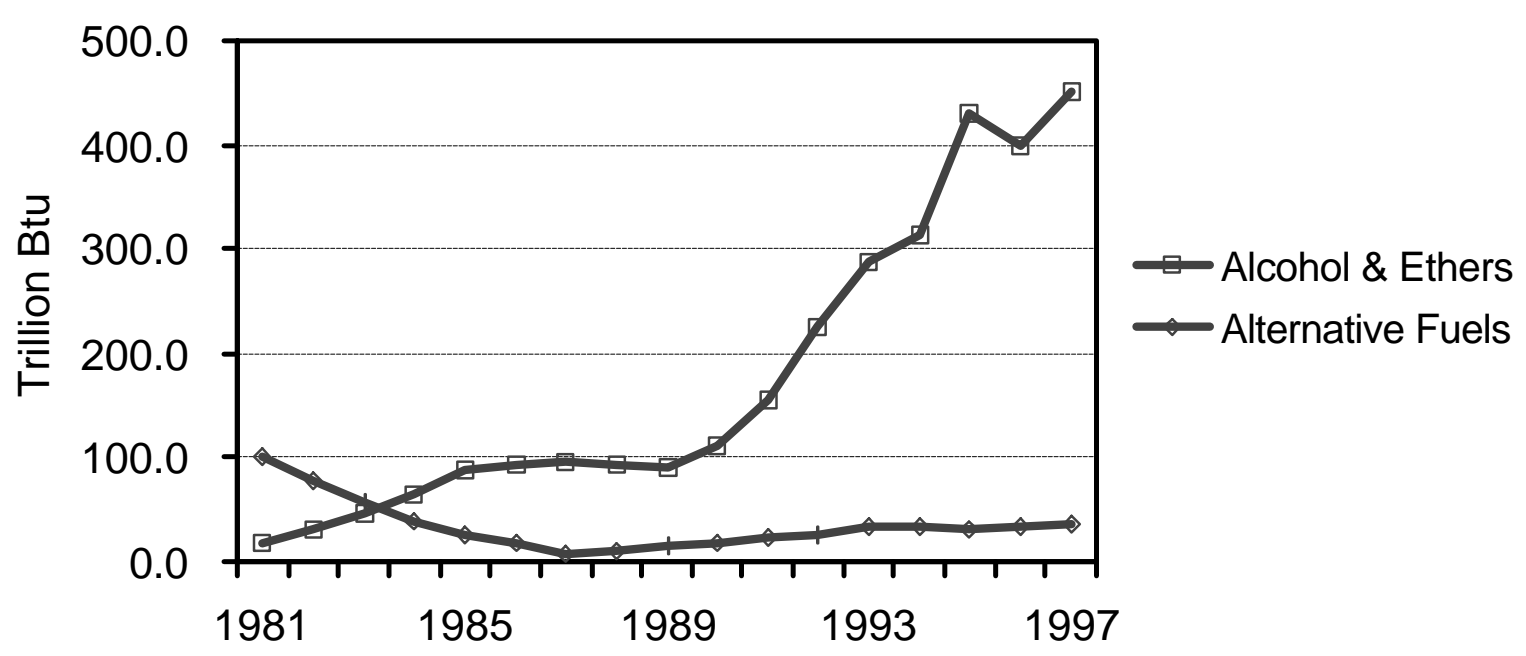

3. Will G-T-L's increase or decrease GHG emissions?

4. Can G-T-L's improve U.S. and Global energy security?

While there are no definitive answers at present, some light can be shed on these issues. Certainly there are sufficient gas resources in the world for G-T-L's to become a significant source of energy for transportation, provided that currently claimed and anticipated future technological advances pan out and that demand for the superior qualities of G-T-L fuels is created by motor vehicle emissions requirements. Low sulfur, low aromatics, high cetane fuels such as G-T-L's certainly can significantly reduce diesel engine emissions. But each of these properties can be achieved via other means. The question is whether F-T diesel will be the most economical choice.

Globally, on a full fuel cycle basis, it appears that G-T-L's could increase net $\mathrm{CO}_{2}$ emissions by as much as 15 percent relative to diesel fuel, but produce slightly less net $\mathrm{CO}_{2}$ emissions in comparison to gasoline vehicles. ${ }^{2}$ But if methane used to produce G-T-L's would otherwise have been vented or flared, production of G-T-L's would instead significantly reduce net GHG emissions. Also, if $\mathrm{CO}_{2}$ generated in the conversion process could be sequestered, perhaps by

\footnotetext{
${ }^{2}$ If excess steam produced in the G-T-L conversion process could be used to generate electricity that would otherwise have been produced from fossil fuels, the impacts of G-T-L production on greenhouse gas emissions would be approximately neutral. If remote gas is the feedstock, this may not be feasible.
} 
being re-injected into the reservoir from which it came, G-T-L's would probably reduce $\mathrm{CO}_{2}$ emissions even relative to conventional diesel fuel.

Finally, the much wider distribution of world natural gas resources suggests that G-T-L production could increase competition in world liquid fuel markets, especially if significant amounts were produced from small to medium-sized fields or from other sources that would otherwise go undeveloped. To the extent that supplies can be developed from sources that are currently uneconomical to exploit, such as coal seam methane, the resource base for world liquid fuels would be extended enhancing the sustainability of motorized transport. Economic theory suggests that it would be very likely that the emergence of a G-T-L market would improve U.S. energy security, even if most G-T-L supplies were imported. A simple simulation model of world liquid fuels markets is used to illustrate how the introduction of a G-T-L's industry would likely reduce both oil prices and the benefits to OPEC of a future oil supply disruption. This appears to be the case even if OPEC itself is a dominant supplier of G-T-L's. 


\section{GAS-TO-LIQUIDS TECHNOLOGY OVERVIEW}

The basic process for converting methane into liquid fuels was first developed in 1923 by Franz Fischer and Hans Tropsch. Real world applications of the F-T process, until recently, had more to do with politics than economics. The Nazis used the F-T synthesis process to produce liquid fuels from coal for their war effort after being cut off from oil supplies in Romania and the Caspian Sea region (PennWell, 1998). The international embargo of South Africa's apartheid regime motivated that nation to create a 150,000 barrel per day (b/d) F-T based synfuels industry. Recently, several important advances in G-T-L synthesis have been announced. All, however, represent improvements on the original F-T method, which consists of three basic steps.

1. In a process known as steam reforming, the chemical bonds of methane are broken down by steam, heat, and a nickel-based catalyst to produce synthesis gas (syngas), a mixture of Hydrogen $\left(\mathrm{H}_{2}\right)$ and carbon monoxide $(\mathrm{CO})$.

2. Next, in the Fischer-Tropsch synthesis reaction, the syngas is blown over a catalyst made of cobalt, nickel, or iron to produce various liquid hydrocarbons, energy, $\mathrm{H}_{2} \mathrm{O}$ and $\mathrm{CO}_{2}$.

3. The temperature of the F-T reaction and the nature of the catalyst used determine the range of hydrocarbons produced. Refining of the hydrocarbon stream to produce precisely the desired finished products completes the conventional Fischer-Tropsch GT-L process. (See, e.g., Fouda, 1998)

The conventional process of steam reforming is both capital and energy intensive. The methane and water vapor must be compressed to 30 times atmospheric pressure and heated to $900^{\circ} \mathrm{C}$. In addition, oxygen must be injected to initiate partial oxidation of the methane and produce still more heat. In general, providing oxygen for partial oxidation requires a plant to liquefy air and separate the oxygen, an expensive operation that comprises approximately 25 percent of the cost of producing syngas and 15 percent of the total cost of liquids production (Fouda, 1998). Several recent advances and research efforts have been directed at reducing the cost of producing oxygen or eliminating the step altogether.

The South African refiner Sasol has accumulated the most experience operating commercial G-T$\mathrm{L}$ facilities. In 1955, Sasol began producing $500 \mathrm{~b} / \mathrm{d}$ of waxy hydrocarbons at a plant at Sasolburg, South Africa. Sasol's process includes all three F-T steps and uses iron-based catalysts similar to those used by the Germans during World War II. Over the years, Sasol developed a slurry phase reactor for F-T synthesis that allowed them to increase throughput per reactor, gaining economies of scale in the entire process (O\&GJ, 1997). In 1993, Sasol began operation of a 2,500 b/d plant utilizing this Sasol Slurry Phase Distillate (SSPD) process. 
According to Sasol, units of $10,000 \mathrm{~b} / \mathrm{d}$ capacity can be constructed at a cost of $\$ 300$ million, with decreases in cost likely for additional units due to efficiencies gained with experience. Such a plant would require 100 million cubic feet per day (Mmcfd) of natural gas to produce 10,000 $\mathrm{b} / \mathrm{d}$ of output $(10,000 \mathrm{cf} / \mathrm{bbl})$. At approximately 1,000 Btu/cf, this implies an overall conversion efficiency of 50-60 percent $(10,000 \mathrm{cf} / \mathrm{bbl} \times 1,000 \mathrm{Btu} / \mathrm{cf}=10 \mathrm{million}$ Btu. One barrel of distillate oil contains about 5.8 million Btu). If feedstock natural gas could be purchased at \$0.50/MMBtu $(\$ 0.50 / \mathrm{Mcf})$, then the feedstock cost per barrel would be $\$ 5$. Sasol estimates other fixed and variable costs of production at $\$ 5 / \mathrm{bbl}$, for a total direct cash cost of production of about $\$ 10 / \mathrm{bbl}$ (O\&GJ, 1997).

Sasol has signed a memorandum of understanding with the Qatar General Petroleum Corporation and Philips Petroleum Co. to build a 20,000 b/d plant at Ras Lafftan, Qatar based on its SSPD process (PennWell, 1998). A feasibility study was to have been completed early in 1998. Together with Chevron, Sasol announced plans for a 20,000 b/d G-T-L plant in Nigeria at an estimated cost of $\$ 500$ to $\$ 600$ million (Remote Gas Strategies, 1998). Since the initial announcement the two companies have completed a feasibility study which recommended that the plant's target capacity be increased to 30,000 bpd. Production is expected in 2003 (Remote Gas Strategies, 1999c).

Shell produced middle distillates, raffinates and waxes at its Bintulu, Malaysia G-T-L plant from 1993 until an explosion on Christmas Day 1997 closed the plant. Shell completed 30 percent of the repairs to the plant and will reopen the facility for full scale production in the second quarter of 2000 (Remote Gas Strategies, 1999b). The rated capacity of the plant to produce only middle distillates is $12,500 \mathrm{~b} / \mathrm{d}$, and it reportedly cost $\$ 850$ million to build (PennWell, 1998). It uses Shell's Middle Distillate Synthesis process which comprises four steps. First synthesis gas is produced using a proprietary syngas process. Next, a F-T process using a metallocene catalyst produces heavy paraffins. Shell is the only company to use metallocene catalysts, which reportedly yield highly consistent products (O\&GJ, 1997). The waxy product is hydrocracked to produce middle distillates, which are then fractionated by conventional distillation. In fact, most of the Bintulu plant's output went to producing specialty waxes, due to their greater profitability. An estimated 30 percent of the plant's capital cost went to the hydrogenation, distillation, and other equipment needed to produce these waxes for a niche market (O\&GJ, 1997).

The maximum economies of scale for the Shell SMDS process would be achieved by a 50,000 b/d plant, four times larger than the Bintulu operation, according to Shell estimates (O\&GJ, 1997). Such a plant is expected to cost $\$ 1.5$ billion, for a capital cost of $\$ 30,000$ per b/d of capacity. Such a large plant would require an enormous gas reserve for feedstock supply. Producing $50,000 \mathrm{~b} / \mathrm{d}$ takes roughly $500 \mathrm{MMcf} / \mathrm{d}$ of gas supply. To operate continuously for 20 years at 80 percent capacity would require reserves of 3 tcf. Only 102 gas fields in the world are estimated to contain in excess of 5 tcf, and only 19 of these are in the Middle East. Another 523 out of the total of 26,556 known fields are estimated to contain 1 to 5 tcf (Ivanhoe and Leckie, 1993). Based on the experience gained at the Bintulu plant, however, Shell reportedly believes that an economically competitive plant could be made as small as $25,000 \mathrm{~b} / \mathrm{d}$, requiring only a 1.5 tcf 
reserve (Petroleum Economist, 1997). Lessons learned at Bintulu will lead to capital cost reductions of at least 30 percent on new units, reducing the plant size necessary for scale economies, Shell reportedly believes.

Exxon announced that it had proven a new G-T-L process it calls Advanced Gas Conversion-21 (AGC-21) by demonstrating it at a pilot plant in Baton Rouge, Louisiana (PennWell, 1998). The AGC-21 process is comprised of three steps. First, natural gas, steam and oxygen are reacted in a fluid catalytic bed to produce synthesis gas. The syngas goes to a slurry reactor where catalysts convert it to paraffinic hydrocarbons. Finally, these are upgraded by means of mild hydroisomerization in a conventional fixed-bed reactor to produce synthetic liquids. Exxon has developed proprietary catalysts for each stage of the process which permit the yield of liquids to range from predominantly diesel and kerosene jet fuel to predominantly naphtha and cat cracker feedstock.

In what was to be a joint project with the Qatar General Petroleum Corporation, Exxon proposed to build a 50,000 to $100,000 \mathrm{~b} / \mathrm{d}$ facility using this process in Qatar, to exploit the vast gas reserves of Qatar's North field. Exxon estimates that such a large plant is required for optimal scale economies, and that only fields in excess of 5 tcf can support an optimally sized plant (PennWell, 1998). Exxon's feasibility study for this project reportedly estimated the capital cost to range from $\$ 1.2$ to $\$ 2.4$ billion, depending on plant size, or about $\$ 24,000 \mathrm{per} \mathrm{b} / \mathrm{d}$.

British Petroleum has announced an alternative plant design that reportedly cuts the capital cost of syngas production by 50 percent. Together with Kvaerner AS, Oslo, BP developed a compact reformer design that removes heat from the catalyst-filled metal tubes inside the reformer, allowing the tubes to be packed together more closely and the overall size of the reactor to be thereby reduced. BP also developed a new cobalt-based catalyst for its process. BP expects the capital cost of such a plant to be approximately $\$ 20,000$ per b/d.

The Syntroleum Autothermal Reforming (ATR) process takes quite a different approach to reducing the costs of G-T-L production. Unlike all other processes, ATR does not require pure oxygen for the partial oxidation of methane to produce synthesis gas. Instead it uses blown air combined with methane (Fouda, 1998). More precisely, Syntroleum believes that it can efficiently convert syngas contaminated with $\mathrm{N}_{2}$ and $\mathrm{CO}_{2}$ at up to 30 percent total inert components (Syntroleum, 1998). The resulting nitrogen-diluted syngas reportedly has a hydrogen/carbon ratio of 2:1, nearly ideal for F-T conversion. The ATR process passes the syngas only once through the F-T section. Because the gas is not recycled through the F-T process, nitrogen does not build up, as it would in a conventional F-T process (PennWell, 1998). Syntroleum (1998) has developed several alternative G-T-L process designs and catalysts to be used under differing circumstances. The company reports that it has developed a "chain limiting" catalyst that prevents the production of waxy long-chain hydrocarbons $\left(>\mathrm{C}_{20}\right)$, while simultaneously minimizing the production of light $\mathrm{C}_{1}-\mathrm{C}_{4}$ hydrocarbons and maximizing production in the transportation fuels range. This development is intended to eliminate the final step of 
hydrocracking to break the longer chain hydrocarbons into transportation fuels, thereby eliminating capital expenditures on refining.

By eliminating the need for an oxygen plant on the front end and mild refining on the back end, Syntroleum is aiming to significantly reduce capital costs and the scale for an economical plant. According to Syntroleum, its G-T-L process can operate economically at 5,000 b/d and, in some cases, as low as $2,500 \mathrm{~b} / \mathrm{d}$. Stationary plants at this scale could tap gas fields as small as $0.1 \mathrm{tcf}$. Syntroleum has proposed a barge-mounted, mobile plant that could potentially exploit fields as small as $0.01 \mathrm{tcf}$, because the useful life of the plant would not be tied to a single location (O\&GJ, 1997; Syntroleum, 1998). Ability to exploit small, isolated fields could be critical to obtaining adequate supplies of low-cost gas feedstocks, an issue discussed in greater detail below. The company believes that small-scale plants can be constructed at a cost of $\$ 12,000$ to $\$ 27,000$ per $\mathrm{b} / \mathrm{d}$. Syntroleum is reported to have estimated the cost of a 2,000 to 2,500 b/d floating unit at $\$ 55$ million (O\&GJ, 1997). Sasol and Norway's Statoil also have stated intentions to develop a floating G-T-L unit to convert associated gas in Norway's offshore reserves into synthetic crude oil. The syncrude would then be mixed with crude oil and delivered ashore. The Sasol/Statoil floating plant would include only the first two steps: syngas production and F-T synthesis (O\&GJ, 1997).

Several companies, including ARCO and Texaco, have announced joint development projects with Syntroleum to test G-T-L technologies. ARCO, which has 7 of the 21 tcf of natural gas resources in the giant Prudhoe Bay field, initiated a pilot project at its Cherry Point Facility in Bellingham Washington in July 1999 (ARCO, 1997). The 70 bpd plant achieved its initial operating targets and is proceeding with its evaluation phase (Remote Gas Strategies, 1999a). Texaco, together with Brown and Root agreed to build a 2,500 b/d plant during 1998-99 to implement Syntroleum's smaller scale technology (Syntroleum, 1997).

The technology for converting natural gas to gasoline via methanol production has been in existence since the 1980s (Corke, 1998a). Mobil's methanol-to-gasoline process uses steam reforming of methane to produce syngas which is then catalytically converted to methanol. The methanol, which contains about 17 percent water, must be dehydrated before being sent on for a final catalytic conversion process that produces a mixture of 44 percent hydrocarbons and 56 percent water (Petroleum Economist, 1997). The output is then distilled to obtain a range of gasolines. Mobil's original New Zealand plant is now owned by Methanex and produces only methanol (Corke, 1998a).

Catalytica received $\$ 2$ million from the U.S. Department of Commerce to develop a G-T-L process based on production of syngas by direct methane oxidation (DMO). While DMO has been attempted in the past, it has generally failed due to difficulties in running the process efficiently (PennWell, 1998). Catalytica believes that a new group of highly selective, single-site, homogenous catalysts could cut plant costs in half and be efficiently operable at commercial scales. The company claims that it has demonstrated feasibility of its DMO process in prototype systems that have converted methane to methanol with 70 percent efficiency. 
Rentech, Inc. constructed a 250 b/d G-T-L pilot plant in Pueblo, Colorado that used partial oxidation to produce syngas and a proprietary iron catalyst to convert it to straight-chain hydrocarbons (PennWell, 1998). The hydrocarbons can then be upgraded and distilled, as market conditions require. The Colorado plant was built to use gas extracted from the Pueblo city landfill, but was eventually shut down because of the landfill's inability to produce sufficient gas. Rentech is currently working on a 350 b/d G-T-L plant to be built in Arunachal Pradesh, India some time in 1999 (Rentech, 1998).

The U.S. Department of Energy (DOE) Office of Fossil Energy's (FE) Gas Processing Program is pursuing research on G-T-L technologies as a way to provide cleaner transportation fuels and promote the use of U.S. gas resources as a substitute for imported oil (U.S. DOE, 1999). Research projects include the Ionic Transport Membrane Syngas project, which is attempting to reduce the capital costs of G-T-L conversion based on partial oxidation by developing oxygenspecific ceramic membranes which permit the passage of oxygen but exclude nitrogen. The goal of this 12-member industry, National Laboratory and university research effort is to develop the process to pre-commercial scale over the next 7 to 8 years. If successful, this technology would eliminate the need for expensive oxygen plants, simplifying G-T-L plants and reducing their capital cost. This and other efficiency improvements could reduce capital costs by 25 percent (O\&GJ, 1997). DOE's research focuses on producing membranes with sufficient strength and mechanical integrity to be practical in commercial reactors (U.S. DOE/FETC, 1999). Even if this research is successful, commercial application is likely to be at least 10 years away (Corke, 1998a). The DOE's Federal Energy Technology Center sponsors several other longer-term research efforts for converting methane to liquid fuels (see, U.S. DOE/FETC, 1999).

Another project at the University of California at Berkeley aims to develop processes for direct conversion of methane to liquid hydrocarbons. This research has focused on oxidative coupling, in which oxygen reacts over catalysts with methane to form water and a methyl radical. The methyl radicals then combine to form a higher alkane, which then dehydrogenates to an olefin (U.S. DOE/FE, 1991; 1998a). These may then be used in conventional processes to produce higher hydrocarbons (U.S. DOE/FETC, 1999). 


\section{POTENTIAL FEEDSTOCK RESOURCES}

Tapping into natural gas resources to produce liquid fuels would considerably expand the total energy resources available to fuel the world's motorized transport. World 1997 crude oil reserves were put at 1,018 billion barrels by the Oil and Gas Journal, and 1,160 Bbbls. by World Oil (U.S. DOE/EIA, 1998d, table 8.1). Natural gas resources were estimated to be 4,947 tcf and 5,177, by the same sources, respectively. Assuming energy contents of $1,027 \mathrm{Btu} / \mathrm{cf}$ for natural gas and 5.910 MMBtu/bbl. for crude oil, world reserves of crude oil amount to $6-7 \times 10^{18} \mathrm{Btu}$, while gas reserves total approximately $5.0 \times 10^{18} \mathrm{Btu}$. While gas reserves are slightly smaller, gas is also being produced at a lower rate. World crude oil production in 1995 amounted to $69.86 \mathrm{MMBD}$, or about $1.5 \times 10^{17} \mathrm{Btu}$, roughly $2-2.5$ percent of total reserves. World production of dry gas, on the other hand, came to $77.92 \mathrm{tcf}$, approximately $0.8 \times 10^{17} \mathrm{Btu}$, roughly 1.5 percent of total reserves. Relative to available reserves, the world is consuming natural gas at about two-thirds to three-fourths the rate at which it is using its oil reserves. Of course, reserves of both crude oil and gas do not represent the world's ultimate resource endowment, but only that portion which has been identified and judged generally economical to produce.

On the other hand, gas consumption has been growing more rapidly than oil use and is expected to continue to do so. The U.S. Energy Information Administration (U.S. DOE/EIA, 1998c, table A2) projects that world natural gas use will increase from 95 quads in 2000 to 174 quads by 2020 , at a rate of just over 3 percent per year. Over the same period oil use is projected to grow from 158 to 237 quads, a growth rate of just over 2 percent per year. This would close the gap between the ratios of consumption to reserves of the two fuels, but not eliminate it.

There is substantial uncertainty about the size of remaining, undiscovered world gas and oil resources. The most recent comprehensive assessment by the U.S. Geological Survey reports a 90 percent confidence interval for undiscovered oil resources of 292 to 1,005 billion barrels. This compares to identified remaining reserves of 1103 billion barrels in 1993. Cumulative production of oil through 1992 amounted to 699 billion barrels, about 50 percent of remaining resources on the pessimistic side, one-third on the optimistic. The 90 percent confidence interval for undiscovered gas is 2,904 to 10,023 tcf, which compares to 5,136 tcf of identified reserves (Masters et al., 1994). Cumulative production through 1992 came to 1750 tcf, just over 20 percent of remaining resources pessimistically, just over 10 percent optimistically. Clearly, the world has not used up nearly as much of its endowment of natural gas as it has of oil. In energy terms, these estimates suggest that there is about 65 percent more gas remaining than oil. If one were to convert the gas to liquid fuels on the basis of 60 percent efficiency, the total remaining energy resources would be roughly equivalent.

Just as there are vast quantities of unconventional oil in the form of heavy oil, tar sands and shale oil that far exceed conventional oil resources, there are also enormous quantities of methane 
present in the earth's crust that exceed conventional gas resources by orders of magnitude. It has been estimated that the amount of methane in coal seams equals the amount of conventional gas reserves (Parson and Keith, 1998). And then there are methane hydrates, deposits comprised of methane molecules trapped in ice, which are found on land in permafrost regions and beneath the ocean floor at depths exceeding 500 meters (U.S. DOE/FE, 1998c). According to a 1995 assessment by the U.S. Geological Survey, U.S. gas hydrate resources range from 100 to 700 quadrillion cubic feet, with a mean estimate of 200,000 tcf, twenty times the optimistic estimate of remaining world reserves of conventional gas. Worldwide estimates of the natural gas content of methane hydrates approach 400 quintillion cubic feet, a staggering figure. There are no proven means of economically recovering methane hydrates, which is a subject of long-term R\&D (U.S. DOE/FE, 1998c). Syntroleum Corp., however, recently obtained a U.S. patent for a system for recovering gas from ocean-bed methane hydrates and converting it to liquid fuels in floating processing plants (Remote Gas Strategies, 1999e). If systems such as this could be proven to be economical, the impact on world liquid fuels markets would be profound.

To be economical, G-T-L conversion projects will require low cost gas, on the order of $\$ 0.50 / \mathrm{Mcf}$ to compete with oil at $\$ 15-\$ 20 / \mathrm{bbl}$. Wellhead prices for natural gas as a gaseous fuel are closer to $\$ 2.00 / \mathrm{Mcf}$. Thus, for G-T-L to be economical, it will probably have to rely on "stranded" gas, resources that are remote from sites of consumption and lack pipeline transport. Today, such resources are either shut-in, flared, vented, re-injected, or simply not booked. Estimates of the quantity of stranded gas are remarkably large. Pintz (1997) asserts that approximately half of the world's 5,000 tcf of proven gas reserves are "stranded," an estimate that has been repeated elsewhere, as well ${ }^{3}$ (Financial Times, 1997). Even the quantities of natural gas annually flared, vented or re-injected are impressive. According to the Oil and Gas Journal (Pintz, 1997, table 1), 87.7 tcf of gas were produced in 1990, 3.2 tcf were flared or vented, and 8.2 tcf re-injected, for a total of 11.5 tcf produced but unused. The U.S. Energy Information Administration (U.S. DOE/EIA, 1998d, table 4.1) reports $3.8 \mathrm{tcf}$ of vented or flared gas and 11.0 tcf of re-injected gas worldwide in 1995, an increase in both categories. If half of this were converted to liquids, 30 billion gallons of additional supply would be created, an amount greater than the total diesel fuel consumption on U.S. highways in 1996 (U.S. DOT/FHWA, 1997, table MF-21) and about enough to make a 20 percent blend with the entire world's diesel fuel demand.

${ }^{3}$ The Financial Times cites a study by petroleum consultants, Wood MacKenzie. Remote Gas Strategies (1998) claims 2,500 to 7,000 tcf of stranded gas. 


\section{DETERMINANTS OF PRODUCTION COSTS AND WORLD SUPPLY}

The feasibility of G-T-L technology has been proven. The key barrier to the proliferation of G-T-L projects is the marginal to unfavorable economics of G-T-L in comparison to petroleumderived fuels. In addition to the current low cost of petroleum fuels, the key issues are (1) the cost of natural gas feedstock, (2) the capital costs for production of syngas, (3) the nature of scale economies, and (4) the capital costs for upgrading of the F-T liquids. Even with recent and expected advances in G-T-L technology competing with petroleum fuels will likely require some sort of clean fuel mandate to confer additional value on F-T fuels.

Capital investment for syngas production, F-T conversion, and upgrading to refine marketable products is the largest component of G-T-L production costs. Costs of past facilities have been quite high. Shell put the cost of its 12,500 bpd Bintulu plant at $\$ 850$ million, $\$ 68,000$ per bpd installed capacity. Shell notes that 30 percent of this cost went to producing specialty waxes, and that what they have learned in the meantime would enable a 20-30 percent cost reduction in a new plant. This would put the cost of a new plant for producing predominantly middle distillates at $\$ 33-38,000$ per bpd. Sasol has cited the costs of new plants at $\$ 300$ million per 10,000 bpd, or $\$ 30,000$ per bpd. Exxon's plans for a plant in Qatar were estimated to cost $\$ 1.2$ billion for $50,000 \mathrm{bpd}$, or $\$ 24,000$ per bpd for an admittedly large scale plant. BP has been quoted as estimating a future cost of $\$ 20,000$ per bpd. Syntroleum has suggested costs ranging from $\$ 60$ million to $\$ 135$ million, depending on conditions, for a 5,000 bpd plant, a range of $\$ 12,000$ to $\$ 27,000$ bpd. Saunders (1998) cites a Syntroleum estimate of $\$ 20,000$ per bpd, and an estimate by the consulting firm CERA of greater than $\$ 25,000$ per pbd. These estimates compare to capital costs of $\$ 10,000$ to $\$ 15,000$ per bpd for a new crude oil refinery.

A parametric analysis of G-T-L production costs has been presented by Corke (1998a). Consistent with the data cited above, Corke puts the investment costs for existing plants at about $\$ 60,000$ per pbd. He cites a 1993 U.S. DOE-sponsored study by Bechtel as giving an overall range of $\$ 38,000$ to $\$ 45,000$ per bpd for plants to be built in the United States at that time. According to industry estimates, such as those cited above, plants could be built today for about $\$ 30,000$ per bpd. In the future, for large scale projects of 50,000 to 100,000 bpd, Corke (1998a) suggests that costs in the vicinity of $\$ 20,000$ per bpd should be achievable.

Using the assumptions listed below in Table 1 for a 20,000 bpd plant, accounting for labor, maintenance, insurance, taxes, and administration, Corke (1998a) estimated a crude oil equivalent price for G-T-L middle distillates of $\$ 16 / b b l$., expressed in terms of a Brent fob crude price. With gas costing $\$ 1.00$ per MMBtu, costs would rise to $\$ 21$ crude oil equibvalent (COE). The $\$ 5 / \mathrm{bbl}$ per $\$ 0.50 / \mathrm{MMBtu}$, is a result of the conversion efficiency, and so can be used reliably as a rule of thumb for relating the cost of gas to the cost of the product. If capital costs could be reduced to $\$ 20,000$ per bpd, middle distillate costs would fall to $\$ 11 / \mathrm{bbl}$ with gas at $\$ 0.50 / \mathrm{MMBtu}$ and 
$\$ 16 / \mathrm{bbl}$ COE with $\$ 1.00 / \mathrm{MMBtu}$ gas. Here a $\$ 10,000$ per bpd change in capital costs translates into approximately $\$ 5 / \mathrm{bbl}$. Other production costs together account for just over $\$ 5 / \mathrm{bbl}$.

Table 1. Assumptions for Corke's Estimates of G-T-L Production Costs

\begin{tabular}{ll}
\hline Plant Life & 25 years \\
\hline Depreciation Period & 20 years \\
Construction Period & 4 years \\
Owners' Equity & $30 \%$ \\
Debt & $70 \%$ \\
Debt Interest Rate & $8 \% / \mathrm{yr}$. \\
General Inflation & $2.5 \%$ \\
Tax Holiday & 10 years \\
Corporate Tax Rate & $35 \%$ \\
Feed-gas Price & $\$ 0.50 / \mathrm{MMBtu}$ \\
Discount Rate & $15 \%$ \\
Capital Cost & $\$ 30,000$ per b/d \\
On-Stream Factor & $90 \%$ \\
Crude Oil Equivalent Cost/Barrel & $\$ 16$ Brent fob \\
\hline
\end{tabular}

Source: Corke, 1998a, table 1.

With production costs this close to crude oil prices, the economic viability of future G-T-L projects is likely to depend on a number of circumstances. Most important is whether refiners will pay a premium for clean middle distillate. Oil producers developing fields with dissolved gas may be willing to pay a premium to avoid flaring or re-injection. Corke (1998a) points out that many of the stranded gas reserves around the world are likely to have associated condensates and natural gas liquids that can only be produced if the gas is produced. These liquids are likely to be priced at a small premium to crude oil, and could strongly influence G-T-L project economics. Assuming production of $5,000 \mathrm{~b} / \mathrm{d}$ condensate per $100,000 \mathrm{Mcf} / \mathrm{d}$ of gas at a value of $\$ 0.50 / \mathrm{bbl}$ premium over Brent crude with a 10 percent royalty, effectively reduces the COE price of G-T-L liquids by $\$ 4 / \mathrm{bbl}$. Even a $\$ 30,000$ per bpd plant paying $\$ 1 / \mathrm{MMBtu}$ for gas could sell middle distillate at $\$ 17 / \mathrm{bbl}$ and make a 15 percent rate of return.

Firms are taking different approaches to reducing the investment costs of G-T-L production. Exxon, BP, BG Technology, Haldor Topsøe, and ICI Katalco are reportedly focusing on combining partial oxidation and steam reforming in a single fluidized-bed reactor to achieve 
economies of scale (Corke, 1998b). The U.S. DOE's sponsorship of research on ceramic membrane technology to inexpensively separate oxygen from air would reduce the cost of partial oxidation methods. Syntroleum and BG Technology have pursued technologies that use air rather than oxygen in the partial oxidation and reforming step, thus eliminating the need for an expensive air separation plant. This should reduce the scale of an economical plant. A number of firms have been working on improved catalysts for slurry, as opposed to traditional fixed-bed-type reactors. The F-T synthesis reactions are exothermic, and slurry reactors permit more precise heat management and therefore temperature control. This permits higher activity catalysts and increased capacities for any given reactor size (Corke, 1998b). Syntroleum and others have reported the development of a "chain-limiting" catalyst system that controls the growth of hydrocarbon chains to produce liquids primarily in the transportation fuels range of $\mathrm{C}_{5}$ to $\mathrm{C}_{20}$, with minimal output of lighter $\mathrm{C}_{1}-\mathrm{C}_{4}$ molecules (Syntroleum, 1998, p. 8). By eliminating the need for hydrocracking of longer chain molecules, these catalyst further reduce capital costs.

Technological developments such as these not only make G-T-L's more competitive with oil, but also reduce the plant size and, hence gas field size necessary for economical operation. The latter could be extremely significant from an energy security perspective because it could open up an entire realm of small field gas reserves to exploitation. 


\section{EMISSIONS BENEFITS OF NEAT AND BLENDED GTL FUELS}

G-T-L processes produce clean, premium-quality liquid fuels with highly desirable properties for reducing automotive emissions. Because sulfur and trace metals tend to poison the catalysts used in G-T-L synthesis, they must be removed from the feedstock when present. The result of F-T synthesis is thus a nearly pure hydrocarbon fuel. When F-T synthesis is directed at middle distillate production it produces predominantly paraffins and n-alpha olefins, and virtually none of the aromatics that exacerbate engine emissions problems. Chain-limiting catalysts can control the production of longer-chain hydrocarbons, eliminating the need for mild hydrocracking and hydroisomerization to break the longer chain paraffins into shorter chain normal and isoparaffins and to eliminate olefins. These steps would otherwise be necessary to improve the cold properties and boiling ranges of the fuels (Corke, 1998a). Finally, distillate fuels produced by F-T synthesis have extremely high cetane ratings (70-76), making them virtually ideal fuels for compression ignition engines. The key properties of conventional, high-quality California diesel, and F-T diesel fuel are compared in Table 2.

Table 2. Approximate Properties of Three Diesel Fuels

\begin{tabular}{lccc}
\hline \multicolumn{1}{c}{ Parameter } & $\begin{array}{c}\text { Standard } \\
\text { U.S. No. 2 Diesel }\end{array}$ & $\begin{array}{c}\text { California ARB } \\
\text { Diesel }\end{array}$ & $\begin{array}{c}\text { "Straight-Run" } \\
\text { F-T Diesel }\end{array}$ \\
\hline Cetane No. & 46 & 49 & $60-80$ \\
Specific Gravity & .85 & .83 & .81 \\
C/H weight ratio & 6.50 & 5.95 & 5.80 \\
Aromatics wt. \% & $28-32$ & $<10$ & $0.0-1^{*}$ \\
Sulfur wt. \% & $<0.05$ & $<0.05$ & $0.001-0.03^{*}$ \\
\hline
\end{tabular}

Source: McMillian and Gautam (1998), table 1. * Also includes data from Martin et al. (1997), table 1.

Heightened concern over the health effects of particulate emissions, together with the lingering problem of ozone pollution promoted by nitrogen oxides emissions are putting increasing pressure on emissions from diesel engines. Current Federal emissions standards for passenger cars and light trucks call for no more than $0.4 \mathrm{~g} / \mathrm{mi}$ of nitrogen oxides and $0.08 \mathrm{~g} / \mathrm{mi}$ of particulates (Davis, 1998, table 3.19). More stringent standards are being formulated by EPA for post-2004, however, which are likely to call for reductions in NOx to $0.2 \mathrm{~g} / \mathrm{mi}$ and eventually $0.05 \mathrm{~g} / \mathrm{mi}$, and reduction of particulate emissions to 0.01 (Walsh, 1998, p. 13). Current California LEV emission standards already require $0.2 \mathrm{~g} / \mathrm{mi} \mathrm{NO}_{\mathrm{x}}$ which must be reduced to $0.05 \mathrm{~g} / \mathrm{mi}$ and particulates will be required to be below $0.01 \mathrm{~g} / \mathrm{mi}$, according to a ruling issued by the California Air Resources 
Board (CARB) this year (Walsh, 1998, p. 9). CARB has decided not to allow light-duty diesels to meet a less stringent standard, a move that will require breakthroughs in emissions control technologies and major changes in diesel fuel formulations. In addition, the CARB has undertaken a major effort to assess the risks of and draft future controls for diesel engines and fuels to reduce toxic emissions (Walsh, 1998, p. 22).

It seems certain that much stricter environmental requirements for diesel fuel are coming, and that they will have a major impact on the properties of diesel fuel. Beginning in 1993, the EPA required a mildly reformulated diesel fuel with 0.05 weight percent sulfur maximum, a minimum cetane number of 40 , and a volumetric maximum of 35 percent aromatics content (McMillian and Gautam, 1998). CARB specification for California diesel require no more than 10 percent aromatics ( $<1.4$ percent poly-aromatics). The EPA has reportedly developed a preliminary proposal to require average sulfur levels in gasoline of $30 \mathrm{ppm}$, and it is very likely that similar action to mandate lower sulfur levels in diesel fuel will have to be taken under pressure to reduce diesel engine emissions (Walsh, 1998, pp. 13 and 23). Proposals under consideration by the California ARB could require even more dramatic and costly changes in diesel fuel. Standards that required significant reformulation of diesel fuel would generate additional economic value for premium quality G-T-L distillates. This would come at a time when the trend in crude oil quality for U.S. refiners is toward heavier feed stocks with higher sulfur content, further increasing the value of sweeter, lighter fuels. With sufficiently strict standards, the current cost disadvantage of G-T-L fuels might be suddenly overcome.

G-T-L distillates have several highly desirable properties for reducing diesel emissions:

1. high cetane numbers of 70 to 76 ,

2. negligible sulfur content,

3. very low aromatic content,

4. high mono- to poly-nuclear aromatics ratio, and

5. low density.

Distillates produced via the F-T process could be used as blend stocks with conventional diesel fuels to improve the average quality of the final product, or could be used as a neat fuel in particularly sensitive applications, such as city buses. Fuels with the properties of F-T diesel have been shown to significantly reduce particulate and NOx emissions from diesel vehicles. Reductions in particulate emissions of 29 percent have been reported by Sasol for F-T diesel produced by their process (Delucchi, 1998, p. 25). Reductions of up to 40 percent in particulate emissions have been reported for Swedish "city diesel" whose sulfur content and cetane ratings are not as good as F-T diesel (Duleep, 1998). With respect to $\mathrm{NO}_{\mathrm{X}}$, reductions of 8 percent have been reported by Sasol (Delucchi, 1998, p. 25), 6-12 percent in other studies (Duleep, 1998).

Numerous studies have demonstrated relationships between diesel fuel properties and emissions (Gerini and Mantagne, 1997; Choi et al., 1997; Bertoli et al., 1997; Kajitani et al., 1997; Li et al., 1997). Several have explicitly tested F-T diesel fuel (Ryan and Montalvo, 1997; Schaberg et al., 
1997; Norton et al., 1998) and confirmed significant reductions of all types of regulated pollutants with F-T diesel. Ryan and Montalvo (1997) tested F-T diesel in a Detroit Diesel Series 60 engine over a cycle similar to CARB's procedure and reported an average of 38 percent less hydrocarbons ( $\mathrm{HC}), 46$ percent less carbon monoxide $(\mathrm{CO}), 8$ percent less nitrogen oxides $\left(\mathrm{NO}_{\mathrm{X}}\right)$, and 30 percent less particulate matter (PM) versus a national average diesel fuel. Schaberg, et al. (1997) obtained similar results: $\mathrm{HC}, \mathrm{CO}, \mathrm{NO}_{\mathrm{X}}$, and PM emissions for F-T diesel were lower by 49 percent, 33 percent, 27 percent and 21 percent, respectively versus standard U.S. diesel fuel (Table 3).

Table 3. Percent Reductions in Emissions in Recent Comparative Studies of F-T and Other Diesel Fuels

\begin{tabular}{|c|c|c|c|c|c|c|}
\hline Authors & Engine & Comparison Fuel & $\mathrm{HC}$ & $\mathrm{CO}$ & NOx & $\mathrm{PM}$ \\
\hline $\begin{array}{l}\text { Martin, et al. } \\
\text { (1997) }\end{array}$ & Various & city-diesel & $20-40 \%$ & $40-70 \%$ & negl. & $30-50 \%$ \\
\hline $\begin{array}{l}\text { Ryan \& } \\
\text { Montalvo } \\
(1997)\end{array}$ & $\begin{array}{c}\text { Detroit } \\
\text { Diesel } \\
\text { Series } 60\end{array}$ & $\begin{array}{c}\text { U.S. average No. } 2 \\
\text { Diesel }\end{array}$ & $38 \%$ & $46 \%$ & $8 \%$ & $30 \%$ \\
\hline $\begin{array}{l}\text { Schaberg, et } \\
\text { al. (1997) }\end{array}$ & & $\begin{array}{c}\text { U.S. average No. } 2 \\
\text { Diesel }\end{array}$ & $49 \%$ & $33 \%$ & $27 \%$ & $21 \%$ \\
\hline \multirow[t]{2}{*}{$\begin{array}{l}\text { Norton, et al. } \\
\text { (1998) }\end{array}$} & $\begin{array}{c}1994 \mathrm{Nav} \\
\text { T444E }\end{array}$ & $\begin{array}{c}\text { U.S. average No. } 2 \\
\text { Diesel }\end{array}$ & $43 \%$ & $39 \%$ & $14 \%$ & $13 \%$ \\
\hline & $\begin{array}{c}19997 \text { Cat } \\
\text { 317B }\end{array}$ & $\begin{array}{c}\text { California No. } 2 \\
\text { Diesel }\end{array}$ & $40 \%$ & $18 \%$ & $12 \%$ & $24 \%$ \\
\hline
\end{tabular}

A group of four European companies measured the exhaust characteristics of 12 alternative formulations of diesel fuel, including F-T diesel and F-T blends (Martin et al., 1997). A major conclusion of the study confirmed the beneficial effects of F-T fuel properties.

"Fischer-Tropsch fuel gives a low level of emissions. The gain compared with already low emissions fuels like J2 and J11 (hydrotreated fuel or citydiesel fuel) varies from 40 to 70 percent for $\mathrm{CO}$, and from 20 to 40 percent for $\mathrm{HC}, 30$ to 50 percent for particulates." (Martin et al., 1997, p. 101)

High cetane number was found to reduce emissions of $\mathrm{CO}, \mathrm{HC}$, and aldehydes. Particulate matter, the fraction of insoluable organics, and poly-aromatic hydrocarbons were reduced by reducing the aromatic content of the fuel and its density. Low density was also one of the only fuel properties found to reduce $\mathrm{NO}_{\mathrm{X}}$ emissions, which were otherwise relatively insensitive to fuel characteristics. 
Norton et al. (1998) tested a F-T fuel obtained from Shell's Bintulu plant against conventional No. 2 diesel and California No. 2 diesel in engine and dynamometer tests. The F-T fuel had a cetane number greater than 74, sulfur content less than $5 \mathrm{ppm}$, and an aromatic content of about 0.3 percent by weight. The F-T diesel required a lubricity additive to meet wear test criteria. The engine tests on 1994 Navistar T444E V8, 7.3 liter diesels were measured on the hot-start portion of the FTP transient emissions test cycle. Neat F-T diesel produced 14 percent less $\mathrm{NO}_{\mathrm{X}}$ and 13 percent less particulate matter, on average in these tests. Results on vehicle tests using model year 1992 to 1994 White-GMC WG64T class 8 tractors re-powered with 1996-7 Caterpillar 317B diesel engines were more impressive. Measured over the West Virginia University 5-mile route on a chassis dynamometer, the four test vehicles produced an average of 12 percent less $\mathrm{NO}_{\mathrm{X}}, 24$ percent less PM, 18 percent less CO, and 40 percent less Total Hydrocarbons (THC), versus the relatively clean California No. 2. Diesel.

Combinations of particulate traps, lean $\mathrm{NO}_{\mathrm{x}}$ catalysts and fuel reformulation could reduce diesel emissions of particulates by 80 percent to over 95 percent, and $\mathrm{NO}_{\mathrm{X}}$ by 60 percent to over 90 percent according to a recent assessment (Mark and Morey, 1999). To achieve these goals, diesel fuel reformulation to achieve the low-sulfur, low aromatics and high cetane properties G-T-L distillates possess will be essential.

Existing studies, however, are far from the final word on the subject of diesel fuel properties and emissions. The European study found that while fuel density and aromatics controlled PM emissions in light-duty engines, in heavy duty engines PM emissions were sensitive only to the oxygen content of the fuel. On the other hand, Norton et al. (1998) found sizable PM benefits for F-T diesel even in heavy-duty engines. Clearly engine design and fuel properties are interdependent in their effects on emissions. McMillian and Gautam (1998) discuss the substantial potential benefits of F-T diesel for enabling changes to diesel fuel injection strategies that should help reduce emissions (Table 4). They further note that F-T diesel also provides a benefit for reducing $\mathrm{NO}_{\mathrm{X}}$ emissions via exhaust gas re-circulation (EGR) because it produces very little soot. EGR controls $\mathrm{NO}_{\mathrm{X}}$ formation by reducing the concentration of oxygen and reducing combustion temperature. Soot build-up in re-circulated exhaust gases increase PM emissions and engine wear.

While neat F-T diesel appears to be a nearly ideal diesel fuel, economic considerations could dictate that F-T diesel will be used predominantly in blends with petroleum-based diesel. The details of how oxygenates, F-T fuel, and other components might be blended to most costeffectively reduce diesel emissions is yet another area for future research. Finally, very low sulfur, low metal contaminant F-T fuel should enable the use of advanced after-treatment systems whose catalysts might otherwise be poisoned by impurities in the fuel (Duleep, 1998). Much research remains to be done before the interactions among engine design, engine control, fuel properties, and after-treatment and emissions are well understood.

Full fuel cycle pollutant emissions have been estimated by Wang (1999) for current and advanced automotive technologies and fuels, using Argonne National Laboratory's GREET model. Near 
term vehicles and fuels were assumed to meet National Low-Emission Vehicle standards and to be representative of model year 2001 vehicles. The EPA's MOBILE 5b emissions model was used to estimate emissions of these vehicles in calendar year 2006. Long- 
Table 4. Potential Benefits of F-T Fuels for Emissions Control via Fuel Injection Strategies

\begin{tabular}{ll}
\hline \multicolumn{1}{c}{ Parameter } & \multicolumn{1}{c}{ Strategy } \\
\hline Injection timing & $\begin{array}{l}\text { Greater degree of timing retardation for } \mathrm{NO}_{\mathrm{x}} \\
\text { control due to reduced soot formation. }\end{array}$ \\
Injection duration & Longer duration, smoothing heat release rates. \\
Rising injection rate & Allows trade-off for lower soot. \\
Decaying injection rate & Allows trade-off for lower $\mathrm{NO}_{\mathrm{x}}$. \\
Peak pressure & May be advanced due to lower mass flow rate of \\
& less dense F-T liquids. \\
Pilot timing & May be advanced due to shorter ignition delay of \\
& F-T, improving thermal efficiency. \\
Post injection & May allow more or later late phase injection \\
& without soot penalty, a plus for catalytic $\mathrm{NO}_{\mathrm{x}}$ \\
& reduction. \\
\hline
\end{tabular}

Source: McMillian and Gautam, 1998, table 2.

term emissions estimates were made by assuming the characteristics of model year 2010 technologies and running the emissions model for the year 2015. Detailed assumptions can be found in Wang (1999) chapter 6. Full fuel cycle results are shown in Figure 2 for hydrocarbons (VOC), carbon monoxide $(\mathrm{CO})$, oxides of nitrogen $\left(\mathrm{NO}_{\mathrm{x}}\right)$ and particulate matter less than 10 microns (PM10). ${ }^{4}$ Surprisingly, Wang foresees advanced diesel fuels, both reformulated and a $50 \%$ RFD/G-T-L blend achieving lower emissions for all four criteria pollutants than even advanced gasoline vehicles.

It seems virtually certain that both major changes in diesel fuel properties and breakthroughs in after-treatment technology will be necessary if diesels are to meet future emissions standards. Clearly, the properties of F-T diesel will give it extra value in this context. Exactly what role G-T-L's will play and how much value that will add, however, is still unclear. Initial assessments by the U.S. Department of Energy indicate that high-quality, very low sulfur diesel fuels (approximately 10 ppm sulfur) can be most economically produced by blendstock selection from existing refineries, but only for limited volumes on the order of 100,000 bld (McNutt and Hadder, 1999). Beyond that level, a variety of more costly methods, including using G-T-L blendstocks would have to be used. Future analyses may shed light on the potential role for G-T-L blendstocks versus other options, such as refinery investment in aggressive hydrodesulfurization and heavy hydrocracking.

\footnotetext{
${ }^{4}$ The graph is truncated at 3 grams per mile to show emissions other than $\mathrm{CO}$ with greater accuracy. Conventional gasoline vehicle $\mathrm{CO}$ emissions are actually $5.7 \mathrm{gpm}$.
} 
Figure 2. GREET Model Pollutant Emissions

Estimates for Passenger Cars

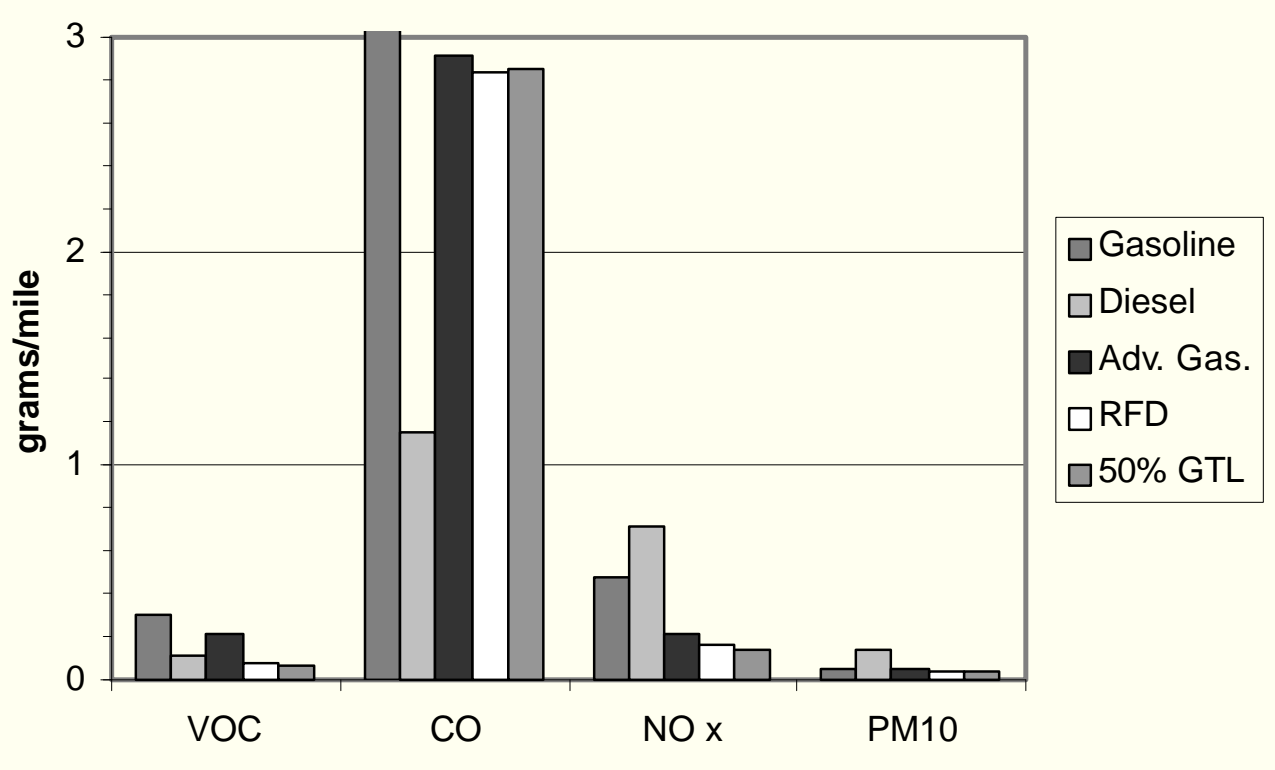




\section{GREENHOUSE GAS EMISSIONS}

The Kyoto Protocol calls for the Annex-1 countries (essentially the OECD plus former Soviet republics) to reduce GHG emissions by 5 percent over 1990 levels, in aggregate, over the 2008 to 2012 period. The United States, a signatory to the agreement which has yet to be ratified by Congress, accepted the goal of a 7 percent reduction. Given that U.S. carbon emissions were 11 percent above 1990 levels by 1997, and the transportation sector's emissions were nearly 10 percent higher, the Kyoto goals present a difficult challenge. As a result, the impact of F-T diesel fuels on total $\mathrm{CO}_{2}$ emissions is likely to be an important factor influencing public policy toward them.

The energy required to reform natural gas, not the F-T synthesis itself, is a potentially significant source of $\mathrm{CO}_{2}$ emissions. The basic chemical reactions of F-T synthesis are particularly well suited to producing paraffins and olefins from natural gas. Methane, with chemical formula $\mathrm{CH}_{4}$ has a nearly ideal $\mathrm{C}: \mathrm{H}$ ratio (1:4) for producing these compounds.

paraffins: $(2 \mathrm{n}+1) \mathrm{H}_{2}+\mathrm{nCO} \rightarrow \mathrm{C}_{\mathrm{n}} \mathrm{H}_{2 \mathrm{n}+2}+\mathrm{nH}_{2} \mathrm{O}$

olefins: $2 \mathrm{nH}_{2}+\mathrm{nCO} \rightarrow \mathrm{C}_{\mathrm{n}} \mathrm{H}_{2 \mathrm{n}}+\mathrm{nH}_{2} \mathrm{O}$

As a result, $\mathrm{CO}_{2}$ is not a significant byproduct of the F-T synthesis reaction. However, a considerable amount of $\mathrm{CO}_{2}$ is produced in the highly endothermic reforming of methane to synthesis gas. Conversion is only 62 percent efficient, so for every mole of $\mathrm{CH}_{4}$ converted to liquid fuels, approximately 0.38 moles of $\mathrm{CO}_{2}$ are produced.

Distillate fuels produced from natural gas have a carbon content similar to, but slightly lower than conventional diesel fuel. Because of its chemical composition, favoring lighter paraffins over heavier aromatics, F-T diesel has a carbon/total mass ratio of 0.848 , versus 0.858 for diesel refined from petroleum, only about 1 percent lower (EEA, 1998, table 1-2). But F-T diesel is about 8.6 percent less dense than petroleum diesel, and has only 5.5 percent less energy per gallon. On the basis of the energy equivalent of a gallon of petroleum-derived diesel fuel, G-T-L diesel should have about 4.4 percent less carbon (Table 5). This simple calculation is confirmed by Norton et al.'s (1998) tests of F-T fuel in heavy duty diesel engines. Their engine dynamometer tests produced an average of $643.75 \mathrm{~g} / \mathrm{bhp}-\mathrm{hr} \mathrm{CO}_{2}$ from conventional no. 2 diesel fuel, $611.49 \mathrm{~g} / \mathrm{bhp}-\mathrm{hr}$ from F-T diesel over the same test cycle, a 5.0 percent reduction in $\mathrm{CO}_{2}$ emissions for the F-T fuel. 
Table 5. Diesel Fuel Carbon Content and Energy Equivalency

\begin{tabular}{lcccc}
\hline & $\begin{array}{c}\text { Higher Heating Value } \\
\left(10^{6} \text { Btu/gal }\right)\end{array}$ & $\begin{array}{c}\text { Density } \\
\text { g/gal }\end{array}$ & $\begin{array}{c}\text { Carbon Mass } \\
\text { Ratio }\end{array}$ & $\begin{array}{c}\text { Carbon / Energy } \\
\text { Ratio (g/diesel- } \\
\text { equivalent gal) }\end{array}$ \\
\hline Petroleum Diesel & 0.1387 & 3192 & 0.858 & 2739 \\
G-T-L Diesel & 0.1310 & 2916 & 0.848 & 2618 \\
\hline
\end{tabular}

Source: Energy and Environmental Analysis, Inc., 1998, table 1-2.

On a full fuel cycle basis, however, G-T-L's carbon emissions may look considerably worse, due to the energy losses in the fuel conversion process. Table 6 compares estimates of the total emissions from production and distribution (not including combustion) of six types of diesel fuel. In general, producing diesel fuel from natural gas increases upstream $\mathrm{CO}_{2}$ emissions by 200 percent relative to conventional diesel fuel, assuming 1995 G-T-L technology. With anticipated advances in conversion technology by 2015, the increase would still be on the order of 100 percent. The difference between Swedish "city diesel" and a blend of 20 percent F-T diesel with Swedish diesel narrows to 15 percent. For 100 percent F-T diesel, upstream emissions are about 30 percent of total fuel cycle emissions.

Taking account of the efficiency of all processes from feedstock extraction, through conversion, transport and handling, up to and including vehicle refueling, conventional petroleum diesel will lose only 10 percent of the original resource's energy content, while F-T diesel will lose about 42 percent. As a result, neat F-T diesel can be expected to produces almost 20 percent more carbon emissions on a full fuel cycle basis than conventional diesel (Table 7). ${ }^{5}$ A blend of 20 percent G-T-L diesel with 80 percent petroleum diesel would result in 4.4 percent more GHG emissions than 100 percent petroleum diesel, but 3.9 percent less carbon emissions than a gasoline vehicle. The difference is due to the greater efficiency of diesel versus gasoline engines. A diesel passenger car is assumed to get 38.5 miles per gallon of diesel fuel, a gasoline passenger car 27.5 mpg of gasoline. Thus, on a full fuel cycle basis, the desirability of G-T-L diesel from a GHG perspective may depend on whether it is replacing diesel or gasoline. That is, if G-T-L diesel blends are viewed as enabling emissions reductions that make diesels a viable powerplant for light-duty vehicles, then use of G-T-L distillates might actually reduce full fuel cycle GHG emissions, in light-duty vehicle applications. If they are viewed simply as a replacement for diesel vehicles, then they would increase GHG emissions.

${ }^{5}$ A report by the U.S. DOE/EIA (1997a, p. xix) indicates only 5 percent more carbon emissions from synthetic diesel derived from natural gas than for conventional diesel (26.8 MMTC/Quad v. 25.5), but does not provide sufficient details to evaluate the numbers which seem out of line with other analyses. 
Table 6. Upstream Emissions from the Production and Distribution of Various Diesel Fuels

\begin{tabular}{lc}
\hline FUEL & $\begin{array}{c}\text { Upstream } \mathrm{CO}_{2} \text { Emissions } \\
\text { (grams/\#2-diesel-equivalent gal) }\end{array}$ \\
\hline Conventional U.S. \#2 Diesel & 1,612 \\
California Diesel & 1,684 \\
Swedish Diesel & 1,791 \\
100\% Fischer-Tropsch Diesel, 1995 & 4.792 \\
100\% Fischer-Tropsch Diesel, 2015 & 3,311 \\
20\% Fischer-Tropsch Diesel, 2015 & 2,068 \\
\hline
\end{tabular}

Source: Energy and Environmental Analysis, Inc., 1998, appendix A.

Table 7. Energy Efficiency and Carbon Emissions for Motor Fuels, 2015

\begin{tabular}{lcccc}
\hline & $\begin{array}{c}\text { Conversion } \\
\text { Efficiency }\end{array}$ & $\begin{array}{c}\text { Efficiency from Feedstock } \\
\text { Production Through } \\
\text { Refueling }\end{array}$ & $\begin{array}{c}\text { Passenger Car } \\
\text { Greenhouse Gas } \\
\text { Emissions (g/mi) }\end{array}$ & $\begin{array}{c}\text { Full Fuel Cycle } \\
\text { Greenhouse Gas } \\
\text { Emissions }\end{array}$ \\
\hline $\begin{array}{l}\text { Conventional } \\
\text { Gasoline }\end{array}$ & $87 \%$ & $84 \%$ & 212.0 & 268.7 \\
$\begin{array}{l}\text { Conventional } \\
\text { Diesel }\end{array}$ & $94 \%$ & $90 \%$ & 209.0 & 247.3 \\
$\begin{array}{l}\text { Fischer-Tropsch } \\
\text { Diesel (100\%) }\end{array}$ & $62 \%$ & $58 \%$ & 207.0 & 293.0 \\
$\begin{array}{l}\text { Fischer-Tropsch } \\
\text { Diesel (20\%) }\end{array}$ & $85 \%$ & $81 \%$ & 208.0 & 258.3 \\
\hline
\end{tabular}

Source: EEA, 1998

Given current international guidelines for computing country GHG emissions, only those emissions within national borders are included. As a result, if G-T-L's were imported, $\mathrm{CO}_{2}$ emissions produced during extraction and processing would not be included in the importing nation's accounts. From this perspective, G-T-L's would reduce carbon emissions for the importing country, even compared with petroleum diesel, but increase emissions from a global perspective. If G-T-L producing countries are signatories to the Kyoto protocol, this might put pressure on them to sequester the emissions from G-T-L production.

Full fuel cycle estimates of emissions of three greenhouse gases, carbon dioxide, methane and nitrous oxide, for diesel fuels made from Fischer-Tropsch processes have been estimated by Wang 
(1999) using Argonne National Laboratory's GREET Model. The full fuel cycle includes production of the feedstock, conversion to diesel fuel plus storage and distribution, as well as vehicular emissions. These estimates give a far more complete picture of the global warming impacts of a particular fuel than the rough, carbon-only calculations just presented. On the other hand, specific assumptions about the fuel cycle are embedded in the final numbers. For example, the GREET model assumes a Syntroleum autothermal reforming process and further assumes that excess steam generated in reforming can be used to generate electricity which would otherwise have to be produced from other sources including fossil fuels. The credit for electricity generation is quite significant, and results in G-T-L diesel having approximately the same full fuel cycle greenhouse gas emissions as low-sulfur, low aromatics, reformulated diesel (RFD) fuel (Table 8). It is arguable whether G-T-L's produced from remote gas would have an opportunity to sell electricity produced from excess steam.

Wang's estimates are in units of grams per vehicle mile, and so reflect the energy efficiency of vehicle technology. This accounts for the apparent advantage of RFD and 50 percent FischerTropsch diesel (FTD) fuels over conventional diesel. The advanced fuels are assumed to be used in a diesel vehicle getting 36.0 miles per gallon, while the conventional diesel vehicle gets only $30.2 \mathrm{mpg}$. The conventional gasoline vehicle does much worse at $22.4 \mathrm{mpg}$. These gas mileage assumptions are built into the estimates shown in Figure 3. Interestingly, Wang's estimates indicate that G-T-L diesel fuel produces no more fuel cycle GHG emissions than advanced, lowsulfur diesel. When G-T-L diesel is made from natural gas that would otherwise be flared, full fuel cycle emissions are reduced by 42 percent for the 50 percent mixture with conventional diesel.

Table 8. GREET Model GHG Emissions Estimates

\begin{tabular}{llrrr}
\hline & \multicolumn{2}{c}{ Feedstock Prod./Dist. Vehicle } & \multicolumn{2}{c}{ TOTAL } \\
\hline Gasoline & 28 & 85 & 401 & 514 \\
Diesel & 21 & 45 & 312 & 378 \\
RFD & 17 & 43 & 257 & 317 \\
50\% GTL & 19 & 48 & 252 & 319 \\
50\% GTL (flared) & 19 & -85 & 252 & 186 \\
\hline
\end{tabular}

Source: Wang, 1999, tables B-I and B-II.

Sequestration of $\mathrm{CO}_{2}$ in depleted oil and gas reservoirs has been proposed has a general strategy for reducing anthropogenic additions of carbon to the atmosphere, and could have applicability to G-T-L production. Injecting $\mathrm{CO}_{2}$ into gas and oil formations is a long-accepted practice in enhanced oil recovery, and injection of $\mathrm{CO}_{2}$ into gas beds could be synergistic to gas exploitation under certain conditions. Deep coal beds contain about the same order of magnitude of methane as global conventional gas reserves, but the methane is adsorbed on coal surfaces. There are an 


\section{Figure 3. GREET Model Estimates of Fuel Cycle Greenhouse Gas Emissions for Fuel Use in Passenger Cars}

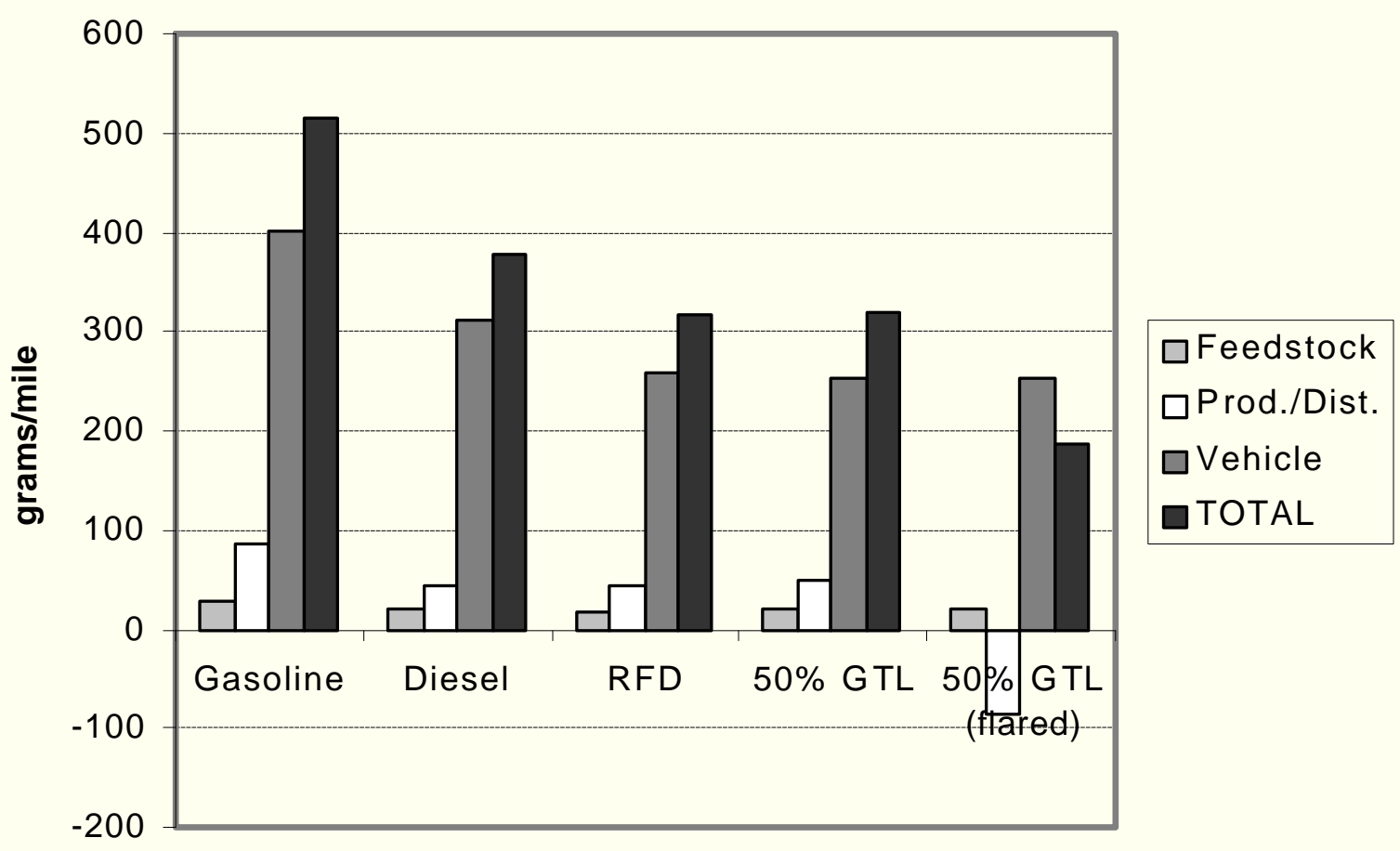

estimated 275 to $649 \mathrm{tcf}$ of recoverable coal bed methane in the U.S. alone, at least four times current U.S. proved gas reserves. $\mathrm{CO}_{2}$ injected into the coal seams is capable of displacing the methane, with two $\mathrm{CO}_{2}$ molecules required to displace one of $\mathrm{CH}_{4}$ (Parson and Keith, 1998). While converting the gas produced to liquids would not produce enough carbon to displace all of the methane produced, it would reduce the amount of $\mathrm{CO}_{2}$ that would have to be acquired from other sources. Furthermore, the $\mathrm{CO}_{2}$ would have to be separated from other effluent gases of the syngas production process, and compressed before underground storage would be possible. The main separation options are chemical or physical adsorption, use of membranes and cryogenic fractionation (Jepma et al., 1996, p. 245).

Sequestration of $\mathrm{CO}_{2}$ from G-T-L production requires capture, separation of the $\mathrm{CO}_{2}$ from effluent gases, and storage, compression and pumping into underground aquifers, other formations, or the deep ocean. Herzog et al. (1997) report a 15-24 percent energy penalty using current technology, for capture of $\mathrm{CO}_{2}$ from natural gas-fired powerplant flue gases. Currently, commercial $\mathrm{CO}_{2}$ capture from flue gas is by chemical adsorption by a solvent. Flue gas is put in contact with the solvent, which selectively absorbs the $\mathrm{CO}_{2}$. The solvent is then sent to a stripper where it is heated to release nearly pure $\mathrm{CO}_{2}$. Pilot plant studies have shown that new solvents and integrated designs can reduce the energy penalty to $10-11$ percent for gas-fired plants. Since less than 40 percent of the methane input is consumed in the F-T process, the rest being converted 
to liquid fuel, an overall energy penalty of about 4 percent might be appropriate for $\mathrm{CO}_{2}$ capture from a F-T process. This would reduce the conversion efficiency from 62 percent to about 58 percent.

Costs of sequestration are highly uncertain at present. The main options for storage of captured $\mathrm{CO}_{2}$ are (Herzog et al., 1997):

- active oil reserves,

- coal beds,

- depleted oil and gas reservoirs,

- deep aquifers, and

- mined salt domes or rock caverns.

Herzog et al. (1997) estimate the costs of geological storage, not including transportation, at $\$ 1-\$ 8 /$ ton of $\mathrm{CO}_{2}$ depending on the particular circumstances. Costs of transportation are cited as $\$ 1-\$ 3 /$ ton $/ 100 \mathrm{~km}$. Costs for deep ocean storage are less well understood but appear to be comparable.

Some information about the potential costs of carbon sequestration can be gotten from experience with the injection of $\mathrm{CO}_{2}$ for enhanced oil recovery, which is a well established technology. The $\mathrm{CO}_{2}$ is typically extracted from natural underground reservoirs and transported by pipeline to the well head. $\mathrm{CO}_{2}$ is transported in pipelines at high pressure (73 atm. or $1072 \mathrm{psi}$.) to reduce the costs of pumping it into the oil reservoir. The price paid for delivered $\mathrm{CO}_{2}$ for enhanced oil recovery in the United States is currently \$10-\$17/ton (Socolow, 1997). Transportation costs are substantial, about $\$ 7$ per metric ton per $250 \mathrm{~km}$, and would be eliminated in the case of in situ GT-L plants. While this would tend to reduce sequestration costs, $\mathrm{CO}_{2}$ produced in methane reformation would not be at high pressures and would be mixed with other gases, so additional pumping and separation costs would be incurred. Orr (1998) reports a range of $\$ 10-\$ 45$ per metric ton of $\mathrm{CO}_{2}$ for storage in conjunction with enhanced oil recovery (Table 9).

Table 9. Costs of Different $\mathrm{CO}_{2}$ Capture and Disposal Options

\begin{tabular}{lcc}
\hline \multicolumn{1}{c}{ Storage Option } & $\begin{array}{c}\text { High Cost Estimate } \\
(1990 \$ / \mathrm{MT} \mathrm{CO} 2)\end{array}$ & $\begin{array}{c}\text { Low Cost Estimate } \\
(1990 \$ / \mathrm{MT} \text { CO2 })\end{array}$ \\
\hline With enhanced oil recovery & $\$ 45$ & $\$ 10$ \\
From industrial sources & $\$ 24$ & $\$ 76$ \\
With geological storage & $\$ 91$ & $\$ 31$ \\
With deep ocean storage & $\$ 91$ & $\$ 31$ \\
\hline
\end{tabular}

Source: Herzog et al. (1997), table 1. 
Sequestration could have a significant impact on the cost of G-T-L fuels. Assuming that gas feedstock cost $\$ 0.50 / \mathrm{MMBtu}$ and that capital and operating costs amounted to $\$ 1.50 / \mathrm{MMB}$ tu of gas processed, 10,000 MCF of gas would produce 48.6 gallons of distillate fuel at a cost of about $\$ 0.42 /$ gal. (Table 10). Assuming that all of the methane not converted to fuel was combusted, $0.21 \mathrm{MT}$ of $\mathrm{CO}_{2}$ would be produced. Assuming a 4 percent energy penalty for sequestration, output would decrease to 45.5 gallons, and $0.23 \mathrm{MT}$ of $\mathrm{CO}_{2}$ would be produced. If $\mathrm{CO}_{2}$ capture could be accomplished at $\$ 10 / \mathrm{MT}$, there were no transport costs, and storage cost only $\$ 1 / \mathrm{MT}$, total costs for production and sequestering would amount to $\$ 0.51 / \mathrm{gal}$., an increase of $\$ 0.09 / \mathrm{gal}$. If sequestration and storage were more costly, and some transport were required, the total cost could rise to $\$ 0.58 / \mathrm{gal}$. It is possible, however, that if the $\mathrm{CO}_{2}$ were injected into an oil or gas formation, it might have value in enhancing resource recovery. Typical values of $\mathrm{CO}_{2}$ in enhanced oil recovery operations are in the range of $\$ 14$ to $\$ 20$ per MT. Including a byproduct value for the captured $\mathrm{CO}_{2}$ would, in the most favorable case, result in slightly lower costs for sequestration versus no sequestration, and in the high cost case reduce the cost increment to $\$ 0.09 / \mathrm{gal}$.

Table 10. Cost of Carbon Sequestration per Gallon of Fischer-Tropsch Product

\begin{tabular}{|c|c|c|c|c|c|}
\hline & \multicolumn{2}{|c|}{ High } & \multicolumn{2}{|c|}{ Low } & \multirow{2}{*}{$\begin{array}{c}\text { No } \\
\text { Sequestration }\end{array}$} \\
\hline & $\$ / \mathrm{MTCO}_{2}$ & \$/gal & $\$ / \mathrm{MTCO}_{2}$ & $\$ /$ gal & \\
\hline Costs of Gas/gal. & & $\$ 0.11$ & & $\$ 0.11$ & $\$ 0.11$ \\
\hline Capital \& Operating & & $\$ 0.34$ & & $\$ 0.34$ & $\$ 0.32$ \\
\hline Capture & $\$ 15.00$ & $\$ 0.075$ & $\$ 10.00$ & $\$ 0.050$ & $\$-$ \\
\hline Transport & $\$ 3.00$ & $\$ 0.015$ & $\$-$ & $\$-$ & $\$-$ \\
\hline Storage & $\$ 8.00$ & $\$ 0.040$ & $\$ 1.00$ & $\$ 0.005$ & $\$-$ \\
\hline Subtotal & & $\$ 0.131$ & & $\$ 0.055$ & $\$-$ \\
\hline Total Cost with no EOR Value & & $\$ 0.58$ & & $\$ 0.51$ & $\$ 0.42$ \\
\hline Value of $\mathrm{CO}_{2}$ in EOR & $\$(14.00)$ & $\$(0.070)$ & $\$(20.00)$ & $\$(0.101)$ & $\$-$ \\
\hline Subtotal for sequestration & $\$ 12.00$ & $\$ 0.060$ & $\$(9.00)$ & $\$(0.045)$ & $\$-$ \\
\hline TOTAL & & $\$ 0.51$ & & $\$ 0.41$ & $\$ 0.42$ \\
\hline
\end{tabular}


Sequestration of $\mathrm{CO}_{2}$ might lead to interesting synergies with G-T-L production. It has already been pointed out that $\mathrm{CO}_{2}$ injected into deep coal seams will displace coal bed methane, but that since the F-T process produces less than 1 molecule of $\mathrm{CO}_{2}$ per molecule of $\mathrm{CH}_{4}$ input, about 80 percent of the $\mathrm{CO}_{2}$ required to displace methane in coal seams would have to be supplied from other sources. While this would most likely mean additional costs for transporting $\mathrm{CO}_{2}$, it would also provide an opportunity for additional carbon sequestration, which might generate revenue making G-T-L more economical.

One proposed source of low-cost natural gas for G-T-L conversion is gas that is currently flared. As noted above, an estimated 3.2 tcf of gas were flared worldwide in 1990. Recent trends have reportedly been towards less flaring and the elimination of venting, so it may be that current levels are lower. As noted above, however, the EIA reports that worldwide venting and flaring actually increased to 3.8 tcf from1990 to 1995 . If transportation fuels were derived from gas that would otherwise have been flared, the reduction in net $\mathrm{CO}_{2}$ emissions would be substantial. For example, for F-T diesel replacing conventional diesel 3,311 - $1612=1699 \mathrm{~g} / \mathrm{gal}$. of net upstream emissions would be added to $9599-10043=-444$ of net vehicular emissions, for a total net emissions of 1,255 g/gallon diesel equivalent energy, an 89 percent reduction in $\mathrm{CO}_{2}$ emissions in comparison to the conventional diesel fuel displaced. 


\section{DISTRIBUTION OF WORLD RESOURCES AND IMPLICATIONS FOR ENERGY SECURITY}

It is very likely that emergence of a G-T-L industry would enhance U.S. energy security, despite the fact that much, if not most, of the fuel would be imported. The term "energy security" can have several meanings. Webster's Ninth New Collegiate Dictionary defines security as: a: freedom from danger: b: freedom from fear or anxiety: c: freedom from want or deprivation. From this definition it is clear that energy security comprises military and strategic, as well as economic, and perhaps also psychological dimensions. The 1991/1992 National Energy Strategy of the U.S. Department of Energy noted that:

"The goals of a healthy environment and reduced dependence on insecure suppliers represent national security, foreign policy, and social benefits to which markets are unlikely to give adequate weight." (U.S. DOE, 1991, p. 2)

Manifestations of the political and military consequences of energy insecurity include conflicts over oil supplies (e.g., the Persian Gulf War), use of oil rents for militarization by hostile states, conflicts between oil interests and other foreign policy goals, etc. Economic costs include the transfer of wealth from oil consumers to oil producers due to non-competitive oil pricing, the loss of potential GDP due to higher oil prices and especially oil price shocks, and the macro-economic losses caused by less than full employment of economic resources during oil price shocks (Greene and Leiby, 1993). While some of the military and strategic energy security issues result from the geographical concentration of oil, most energy security concerns are the result of the exercise of market power by oil producers. Estimates of the past costs to the U.S. economy of the use of monopoly power by the OPEC cartel range from $\$ 1$ to $\$ 4$ trillion dollars (Greene and Leiby, 1993). Potential economic costs of a single future oil price shock have been put at roughly half a trillion (Greene et al., 1998). The costs the U.S. economy incurs when oil prices are raised above competitive market levels depend on the importance of oil in the economy (as reflected in the oil cost share of GDP), the quantity of oil imported (which determines the transfer of wealth), and the price elasticities of oil supply and demand. From the economic perspective, improving energy security becomes a matter of reducing the quantity of oil imported, increasing the economy's ability to substitute other energy sources for oil, and reducing the potential market power of oil producers.

Liquid fuels from natural gas have the physical and chemical properties to be readily substitutable for conventional petroleum-based fuels, and should reduce petroleum, but not total energy, imports. What is not clear is whether increased use of G-T-L fuels will lead to a more competitive world liquid fuels market. Several OPEC members have vast, untapped low-cost gas reserves that could give them the ability to garner a major share of any worldwide G-T-L fuels market. Would a major role for OPEC states in a G-T-L's market erase the potential energy 
security benefits for the United States? The economic theory of competition in a joint oil-gas liquid fuels market is developed below. It implies that the answer is complicated, depending on several key factors, but that under most circumstances U.S. energy security would improve. A simple model of world liquid fuels markets is used to illustrate this point.

The energy security implications of liquid fuels derived from natural gas will undoubtedly depend on both the availability of low-cost natural gas and its geographical distribution. As will be shown below, economic theory suggests that there must be substantial low-cost gas supplies outside of OPEC nations for G-T-L's to have major energy security benefits. Fortunately, the geographical distribution of world natural gas resources is fundamentally different from that of oil resources. Whereas OPEC nations hold three-fourths of the world's proven oil reserves (U.S. DOE/EIA, 1998d) and more than half of the worlds ultimate resources of conventional oil (Masters et al., 1994), their corresponding shares of gas reserves and resources are about 40 percent and 35 percent. Two-thirds of the world's supergiant ( $>5$ billion bbls.) and megagiant ( $>50$ billion bbls.) oil fields are found in the Mideast, but only 19 of the 102 largest natural gas fields are located there (Ivanhoe and Leckie, 1993). Russia, with its vast land area, contains the world's largest natural gas resources. With nearly one-third of the world's proved gas reserves and roughly the same share of estimated ultimate resources, Russia is the Saudi Arabia of natural gas.

Gas reserves are also distributed quite differently among OPEC member states. Where as Saudi Arabia dominates OPEC oil reserves with one-third of the total, Iran has the lion's share of OPEC's gas reserves: 35 percent (Figure 4). Qatar, with less than 0.5 percent of OPEC's oil, contains 12 percent of its gas, making it the second largest resource holder. The United Arab Emirates, Saudi Arabia, and Venezuela follow, with 10 percent, 9 percent and 7 percent of OPEC's total respectively. While combined oil and gas resources are more evenly distributed within OPEC (Figure 5), the overall balance of power is not drastically changed. The top three in oil (Saudi Arabia, Iraq, Iran) are still the top three in oil plus gas (Saudi Arabia, Iran, Iraq), and together still hold 60 percent of OPEC's ultimate resources. If OPEC were to attempt to behave as a joint liquid fuels cartel, the more even distribution of resources would make it more difficult for a single nation to lead, but it is not clear whether this would also make it more difficult for OPEC members to reach a consensus.

To be economical, G-T-L production will require low cost gas, on the order of \$0.50/MMBtu. In the United States in 1997, wellhead gas prices averaged \$2.42. In Europe, prices for gas imported via pipeline range between $\$ 3$ and $\$ 4$ per MMBtu. Because of this large price gap, methane that can be brought to market as a gaseous fuel via pipelines will not be available for conversion to liquid fuels. This limits the resources available to G-T-L conversion to remote or stranded gas, or gas that is currently flared, vented or re-injected due to lack of access to a local market or nearby pipeline. Much less is known about the extent and distribution of these resources. In large part, this is due to the fact that there is little incentive for energy companies to explore and document the extent of resources for which there is no market. In many parts of the 
Figure 4. Distribution of U Itimate Resources of Oil and Gas with in OPEC, 1993

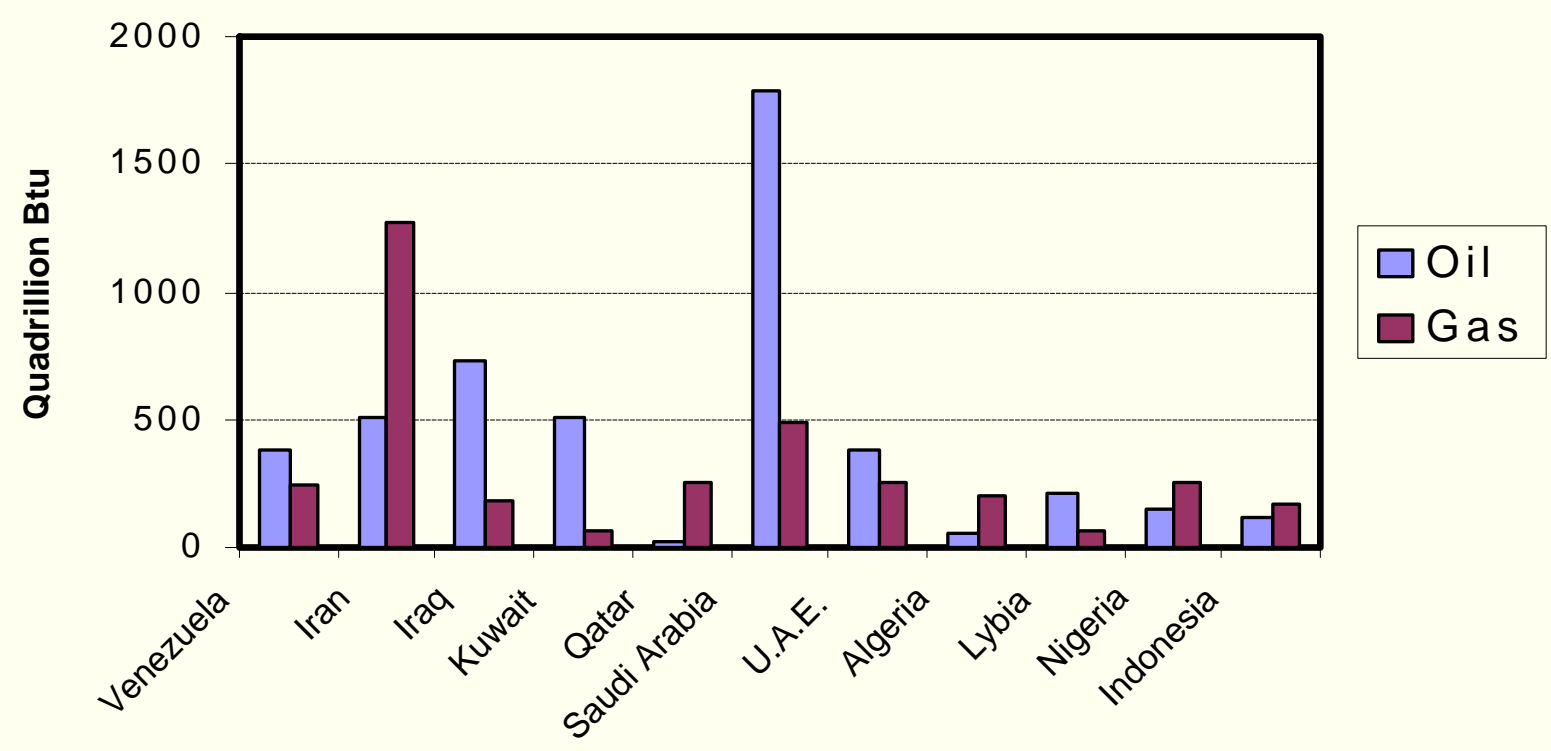

Figure 5. Concentration of Energy Resources in OPEC, 1993

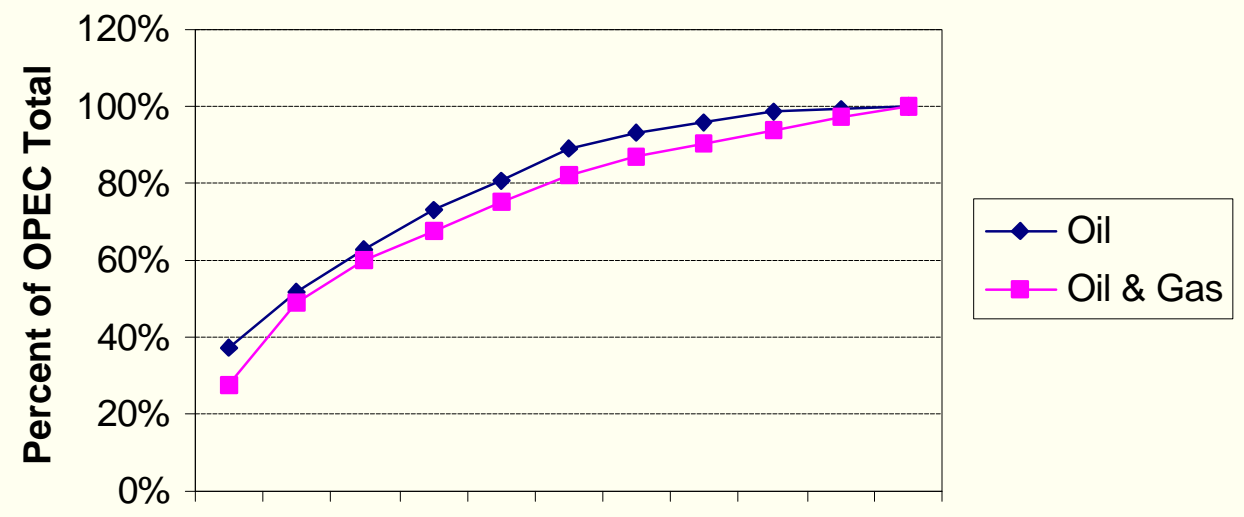

Countries Ranked by Size of Resources 
world gas deposits are known to exist but are not tallied in reserves because the infrastructure to gather and distribute the gas is unavailable (U.S. DOE/EIA, 1997a, p. x).

One set of estimates of the quantity and regional distribution of stranded gas, prepared by the Atlantic Richfield Co., has been published (Saunders, 1998). According to this estimate, there are 5,214 tcf of stranded gas resources in the world, of which 70 percent are in the states of the former Soviet Union or in the Middle East (Figure 6). For purposes of comparison, 5,000 tcf is approximately equal to the world's identified reserves of gas $(5,136 \mathrm{tcf})$, and about half of the U.S. Geological Survey's (Masters et al., 1994, table II) modal estimate of the world's ultimate resources $(11,568 \mathrm{tcf})$. Some of this gas is already being developed for conversion to LNG, enhanced oil recovery, and other purposes.

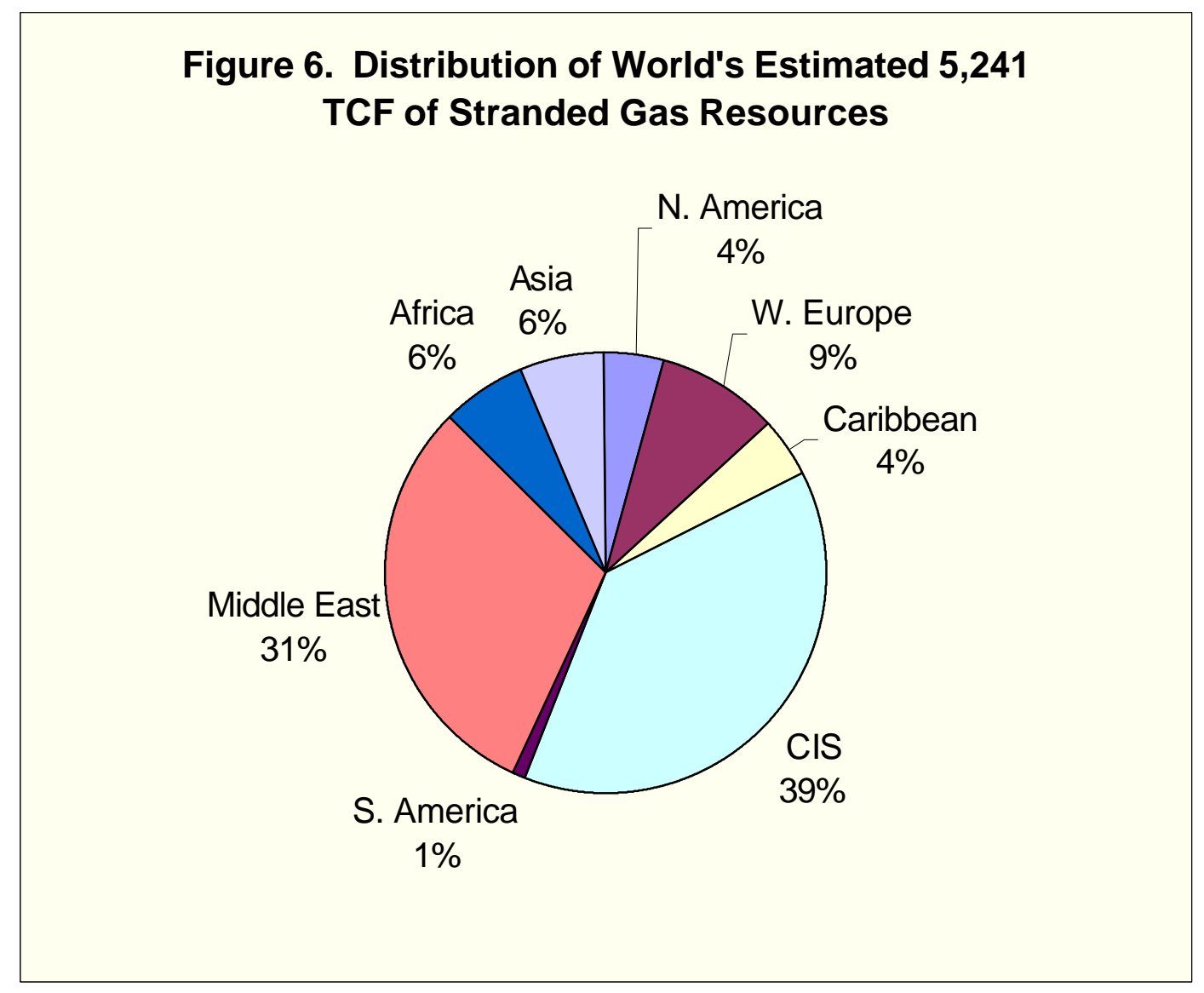

A 1993 assessment of gas potentially available for conversion to liquid fuels found that while a great deal of gas was potentially available, nearly all of the low cost gas appeared to be in the Middle East. The study calculated costs of producing gas from the world's undeveloped, nonassociated reserves for the purpose of determining the potential supply of methanol produced from natural gas (Energy and Environmental Analysis, Inc, 1993). Gas fields in 32 countries containing 90 percent of the world's proved gas reserves were individually examined. The costs 
of development were estimated for each field using a set of standard economic assumptions and taking into consideration field size, depth, location, and yields of condensate and natural gas liquids. Only fields larger than 70 to $100 \mathrm{bcf}$ were considered. Of the 2,065 tcf of eligible gas identified, 665 tcf was estimated to be available at less than $\$ 1 / \mathrm{Mcf}$ (Figure 7). Of this, more than 80 percent can be found in three countries: Iran (296 tcf), Qatar (128 tcf) and Saudi Arabia (96.3 tcf). While states of the former Soviet Union (mostly Russia) have vast quantities of undeveloped, nonassociated gas, an estimated 877 tcf, only 9 tcf were estimated to be available at less than $\$ 1 / \mathrm{Mcf}$, primarily due to higher costs for transportation to an ice-free port. About half of the relevant former Soviet gas reserves would become available between $\$ 1$ and $\$ 3 / \mathrm{tcf}$, according to the study's estimates. The study did not comprehensively evaluate associated gas, nor did it consider fields under about $0.1 \mathrm{tcf}$ in size, nor the possibility of offshore conversion of G-T-L's.

\section{Figure 7. Estimated Distribution of Gas Resources by Field Size in TCF}

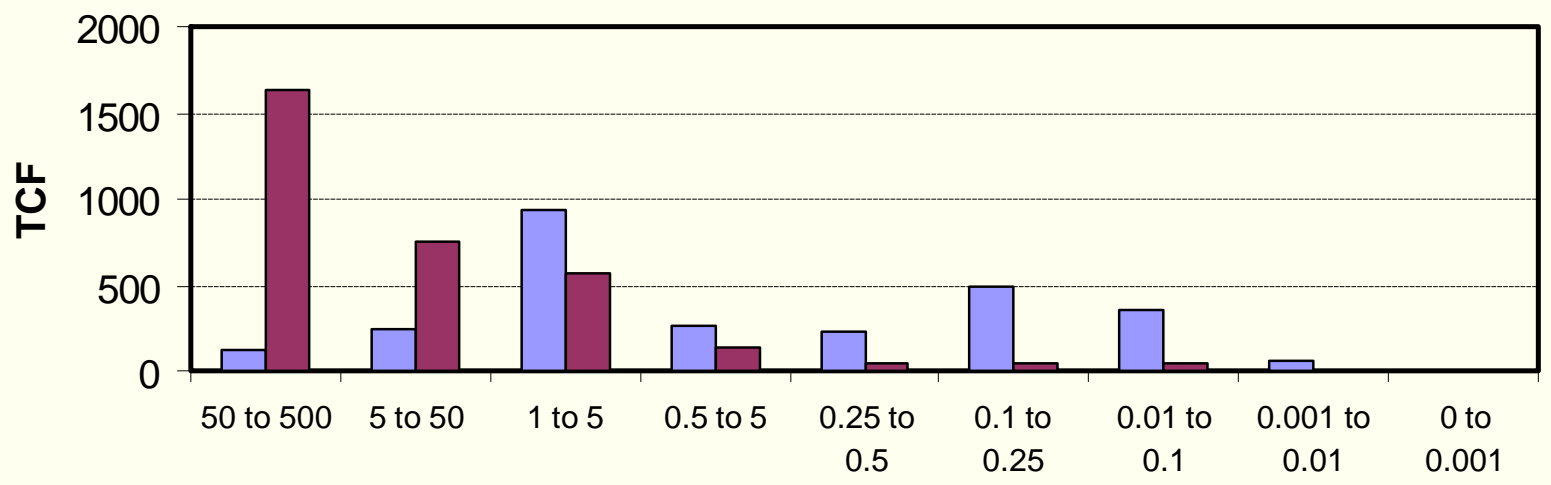

U.S. Europe, Canada $\square$ Rest of World

The 1993 EEA (1993) study did calculate cost estimates for production from associated and dissolved gas for a sample of 17 fields. Development costs ranged from 5 cents per Mcf to $\$ 3.83$ (1988 \$). Note that to support even a 5,000 bpd G-T-L conversion plant would require gas production of approximately $1.9 \mathrm{bcf} / \mathrm{yr}$. Six fields, with a combined annual production capacity of 289 bcf had estimated costs of less than $\$ 1$ per Mcf (Table 11). The gas from these six fields would be enough to produce 1.2 billion gallons of distillates per year. Worldwide, the total amount of associated gas produced each year and not used is far higher than the few fields shown in Table 11, as the estimates of 3.8 tcf vented or flared and 11.0 tcf re-injected in 1995 suggest. 
Table 11. Summary of Resource Costs for Associated Gas

\begin{tabular}{lccc}
\hline \multicolumn{1}{c}{ Field } & $\begin{array}{c}\text { Reserves } \\
\text { (bcf) }\end{array}$ & $\begin{array}{c}\text { Net Gas } \\
\text { (bcf/yr) }\end{array}$ & $\begin{array}{c}\text { Price } \\
(1988 \$ \text { Mcf) }\end{array}$ \\
\hline La Paz Gas Cap Blowdown (Venezuela onshore) & 2,200 & 76.9 & $\$ 0.05$ \\
Onshore Solution Gas Field (U.A.E.) & 1,113 & 38.9 & $\$ 0.11$ \\
Offshore Solution Gas Field (U.A.E.) & 1,871 & 65.4 & $\$ 0.18$ \\
Onshore Solution Gas Field (Algeria) & 1,597 & 55.9 & $\$ 0.59$ \\
Offshore Solution Gas Field (Indonesia) & 206 & 7.3 & $\$ 0.79$ \\
Obagi Gas Cap Blowdown (Nigeria Onshore) & 1,282 & 44.9 & $\$ 0.84$ \\
Offshore Solution Gas Field (Trinidad) & 197 & 6.9 & $\$ 1.20$ \\
Fateh SW Injected-Gas Blowdown (U.A.E. Onshore) & 300 & 10.9 & $\$ 1.22$ \\
Oseberg Injected-Gas Blowdown (Norway Offshore) & 3,811 & 134.0 & $\$ 1.34$ \\
Onshore Solution Gas Field (Nigeria) & 275 & 9.6 & $\$ 2.26$ \\
Onshore Solution Gas Close to PL (Venezuela) & 54 & 1.9 & $\$ 2.32$ \\
Onshore Solution Gas Close to PL (Trinidad) & 36 & 1.2 & $\$ 2.44$ \\
Onshore Solution Gas Field (Argentina) & 226 & 7.9 & $\$ 2.81$ \\
Delta South Gas Cap Blowdown (Nigeria Offshore) & 1,080 & 37.8 & $\$ 3.03$ \\
Offshore Solution Gas Field (Nigeria) & 136 & 4.8 & $\$ 3.37$ \\
Offshore Solution Gas Field (Trinidad) & 36 & 1.2 & $\$ 3.70$ \\
La Paz Solution Gas (Venezuela Onshore) & 54 & 1.9 & $\$ 3.84$ \\
\hline
\end{tabular}

a "Blowdown" gas refers to gas that is not dissolved in oil but produced from a "gas cap" on top of the oil in a resevoir.

Source: EEA, Inc., 1993, table C-11.

How much of this potential total could be made available at an attractive price for G-T-L conversion has yet to be determined.

It is possible that a great deal more gas exists in small fields than is presently recorded. Figure 7 shows an estimated distribution of world gas resources by field size for the intensively developed regions of the United States, Canada and Europe, versus the rest of the world (ROW). The graph is based on Ivanhoe and Leckie's (1993) tallies of gas fields by size interval. A crude linear interpolation method was used to determine the average size of fields in a category. The data are not intended to be precise, but merely illustrative of the fact that the United States, Canada and Europe have developed a great deal of gas from smaller fields, while the ROW has not. Indeed, three-fourths of the world's known gas fields were in the United States. This is taken to reflect 
the intensity of exploration and development more than the physical distribution of resources. As Ivanhoe and Leckie (1993) point out, the dearth of small fields in the ROW is evidence of underreporting more than nonexistence. If this is true, then substantial amounts of gas are present in smaller fields in areas of the world where the absence of accessible markets for the gas makes it uneconomical to discover and develop the gas. It appears that the potential of these fields to provide low-cost gas for conversion to liquids has not been assessed.

But could small, stranded fields become an economical source of gas for G-T-L production? As we have noted above, large-scale G-T-L conversion methods require major gas fields of 1-5 tcf in size. Processes that eliminate the need for oxygen plants and on-site refining, may achieve economies at much smaller scales. Claims have been made that fields as small as 0.1 tcf could be exploited by advanced technology stationary plants. Others put the minimum reserve size at 0.5 tcf (Zeus, 1998a). As yet unproven concepts for exploiting offshore fields as small as 0.01 tcf with floating G-T-L plants have also been proposed (Syntroleum, 1998).

Natural gas that is currently vented or flared is a particularly attractive target for G-T-L conversion because its value is obviously low (possibly negative) and because converting it to usable liquid fuels would result in a substantial net decrease in full fuel cycle GHG emissions. Of the $3.8 \mathrm{tcf}$ vented or flared in 1995, $451 \mathrm{bcf}$ is attributed to North America and $284 \mathrm{bcf}$ of that to the United States. An estimated 1.6 tcf are vented or flared in Africa, 926 bcf of that in Nigeria (Figure 8). The Middle East total of 914 bcf is primarily attributable to two nations, Saudi Arabia (449 bcf) and Iran (410 bcf). Information on venting and flaring in the CIS is not generally available, so the total of 3.8 is almost surely an underestimate. Unlike vented or flared gas, re-injected gas generally has a positive value for enhanced oil recovery. Nevertheless, that value is likely to be low, making it at least a possible source of low-cost gas for G-T-L conversion. The United States, at $3.6 \mathrm{tcf}$, re-injects more gas than any other country in the world (except possibly Russia, for which data are not available). Algeria is second, with 2.4 tcf, followed at a distance by Iran (0.9 tcf), and then Indonesia, Norway, Venezuela, and Canada, each with about $0.5 \mathrm{tcf}$ re-injected each year. The $3.8 \mathrm{tcf}$ of gas vented, flared or re-injected in the United States each year is enough to make 16 billion gallons of distillate fuel, roughly half the amount consumed on U.S. highways each year (U.S. DOT/FHWA, 1997, table MF-21). It is not at all clear, however, how much of this potential resource could economically be converted. That would require detailed assessment of each potential resource. What is clear is that the maximum possible amount of fuel is very significant.

Recently, a joint agreement to conduct a market study matching the world's stranded and associated gas reserves to gas-product alternatives, including G-T-L, was announced by Petroconsultants and Zeus Development Corporation (Zeus, 1998b). The firms noted that they had identified 2,000 candidate fields for study, each containing a minimum of 0.05 tcf of gas. The field-by-field analysis is to be reported on at the Offshore Natural Gas Conference, April 28-30, 1999. Arthur D. Little of Canada has completed a proprietary study of G-T-L that reportedly includes an assessment of which worldwide gas reserves are the most suitable for G-T-L development (Georgiou, 1998). While the cost of this study (approximately $\$ 30,000$ ) is too high 


\section{Figure 8. Worldwide Venting, Flaring and Re-injection of Natural Gas}

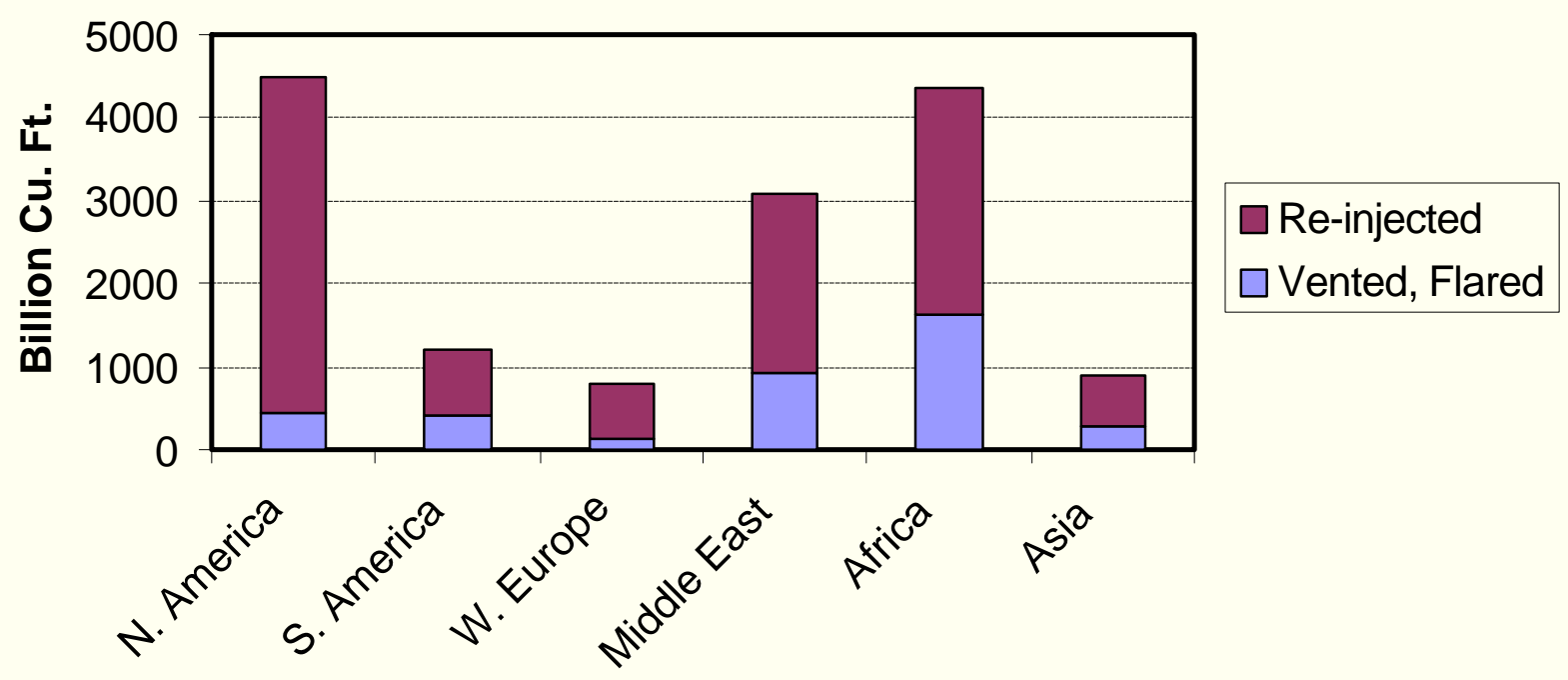

to be included here, it may be that studies such as the two mentioned above can provide the data needed to evaluate the true supply curve for G-T-L feedstocks. That supply curve is likely to be composed of many different sources. It is also likely that special considerations, the need to avoid venting or flaring, the opportunity for synergistic production of gas, NGLs, condensate and petroleum, etc., are likely to be critical to economic viability. 


\section{WORLD OIL MARKETS AND IMPLICATIONS FOR ENERGY SECURITY}

The development of a global G-T-L industry would enhance U.S. energy security if it diversified the sources of liquid fuel imports and reduced the market power of the OPEC cartel. Market share is critical to market power, as will be shown below. OPEC states do not hold the predominant share of the world's gas resources as they do oil. But if the majority of the ROW's remaining gas resources are claimed for higher-value, gaseous markets such as electricity generation or home heating, this could leave OPEC members with a much greater share of the G-T-L market. This section and an appendix explore what economic theory has to say about the potential consequences of a new G-T-L industry on OPEC market power. A simple model of the world's liquid fuels market is then used to illustrate possible future impacts on oil prices and OPEC profits.

Economic theory can shed some light on whether and under what conditions G-T-Ls might improve U.S. energy security. It is likely that OPEC members would be major producers of G-T-L's because many have significant, unutilized reserves of natural gas. Indeed, the world's largest G-T-L plant is planned to be built in Qatar, in a joint venture with Sasol and Philips Petroleum. If OPEC members are major G-T-L producers, will the introduction of G-T-L's have any energy security benefits for world oil consumers? In this section, the theory of a profit-

maximizing monopolistic cartel is used to demonstrate how the market power of the cartel, i.e., its ability to raise prices above competitive market levels and sustain them there, is influenced by the basic parameters of world demand, and by supply from nations outside the cartel. First, the case of a simple monopoly is introduced and then the effect of competitive producers on cartel market power is demonstrated. In the appendix, a replacement fuel derived from natural gas is introduced as a substitute for petroleum and the effect on cartel market power is analyzed. The development of this theory allows us to analyze the conditions under which the introduction of replacement fuels derived from natural gas could reduce OPEC market power and thus improve energy security.

Although oil is clearly a finite resource, the theory of exhaustible resources is not used here. Over the past two decades, a consensus has arisen among most energy economists that the exhaustion dates for world petroleum are sufficiently far off and, due to technological change, sufficiently uncertain that markets do not treat oil as if there were a fixed, known amount to be used up (e.g., see Banks, 1986; Watkins, 1992; Mabro, 1992; Gordon, 1994). Rather, oil reserves are treated as inventories which can be maintained and expanded by the expenditure of capital and labor, much like any other commodity (Adelman, 1990).

Suppose that all the world's oil were produced by a single state-owned company. How would it price its oil? If we assume that the country's goal is to maximize its profits ( $Ð$ ), the answer is straightforward. Let $\mathrm{Q}(\mathrm{P})$ represent the world's demand for oil as a function of its price $(\mathrm{P})$, and 
$\mathrm{C}$ represent the cost of producing a barrel of oil, which for simplicity we assume is constant. The monopolist's goal is to choose the level of production that will maximize its profits.

$$
\operatorname{Max} \prod_{Q}=P \cdot Q(P)-C \cdot Q(P)
$$

The first order condition for maximization is,

$$
\frac{\mathrm{d} \Pi}{\mathrm{dQ}}=\mathrm{P}+\frac{\mathrm{dP}}{\mathrm{dQ}} \mathrm{Q}-\mathrm{C}=0
$$

from which, by noting that $(\mathrm{dP} / \mathrm{dQ})(\mathrm{Q} / \mathrm{P})=$ â, the price elasticity of petroleum demand, and rearranging terms we arrive at the following formula for the monopolist's profit-maximizing price.

$$
P=\frac{C}{1+\frac{1}{\beta}} \quad, \quad \beta<-1
$$

The amount that a monopolist can drive the price above the cost of production, $\mathrm{C}$, while increasing profits is a measure of its market power, and depends on the price elasticity of demand. If $\hat{a}=-2$, for example, $\mathrm{P}=2 \mathrm{C}$, but if demand is more elastic, say, $\hat{\mathrm{a}}=-3$, then $\mathrm{P}=1.5 \mathrm{C}$. In this case, if the monopolist tries to drive prices above $1.5 \mathrm{C}$, its total profit will begin to decline. Given no competition, and no alternatives to petroleum as a feedstock for liquid fuel production, all that can be done to reduce the monopolist's market power is to increase the price elasticity of demand for petroleum. Either the energy-using technology of transportation would have to be changed (e.g., by developing new options for increasing fuel economy) or consumers would have to change their habits and preferences for motorized travel.

\subsection{THE OPEC CARTEL AS IMPERFECT PARTIAL MONOPOLIST}

This simple model can be made more realistic by recognizing that there are other producers of oil besides the cartel, but that the cartel still controls a large enough share of production to influence prices. OPEC, for example, supplied 55 percent of the world's oil in 1973 and supplies 43 percent today. We assume the cartel's goal is still to choose a level of production that maximizes its profits. In this case, however, profits are on the cartel's share of world oil demand, which equals total demand $(\mathrm{Q})$ minus the amount supplied by the ROW's producers, $\mathrm{q}_{\mathrm{s}}$.

$$
\operatorname{Max} \prod_{Q}=P\left(Q-q_{s}\right)-C\left(Q-q_{s}\right)
$$


This slightly more complicated maximization problem leads to a slightly more complex pricing rule.

$$
P=\frac{C}{1+(1+\gamma) \sigma \frac{1}{\beta}}
$$

In equation (5) ó is the cartel's market share and a is the change in ROW oil production in response to a change in cartel production, at constant price. That is, if the cartel cuts production by one barrel, how many additional barrels will the ROW suppliers produce? In effect, the term $(1+\tilde{a}) \hat{o}(1 / \hat{a})$ is the inverse of the price elasticity of net demand for the cartel's oil. Assume again that $\hat{a}=-3$, but also that $0=0.5$ and $\tilde{a}=-0.5$. In this case $\mathrm{P}$ is not $1.5 \mathrm{C}$, but only $1.09 \mathrm{C}$. A cartel's profits would be greatly reduced because even the limited competition undermines its market power.

The realism of this simple theory can be increased by admitting that crude oil is not the only feedstock from which liquid transportation fuels can be made. In the past, crude oil has been such a predominant feedstock that the existence of potential alternatives has had little practical consequence. However, if premium alternative transportation fuels can be made from natural gas at competitive prices this could change, as we have pointed out above. What would be the implications for the monopoly power of an oil cartel? The question is made more complicated by the fact that the cartel itself could be a major producer of G-T-L petroleum substitutes because of its vast reserves of undeveloped gas, gas which could make the cartel a significant low-cost producer.

The existence of a significant substitute for petroleum would change market competition in at least three significant ways. First, the cartel's pricing problem would now include the joint maximization of profits over two feed stocks instead of just one. This makes the pricing formula considerably more complex. A detailed derivation is provided in the appendix. Second, the creation of a new substitute increases the world price elasticity of crude oil demand, which would lower the optimal monopoly price of oil, whether or not the cartel chooses to produce any G-T-L's. Third, because the distribution of gas reserves among cartel members is substantially different from the distribution of oil reserves, there is a change in the balance of power within the cartel that could affect its internal decision making, most importantly its ability to agree on and enforce optimal monopoly pricing decisions. The implications of these changes for market power in world oil markets is explored below using a simple simulation model.

\subsection{ENERGY SECURITY IMPACTS OF G-T-L: A SIMULATION}


Intuitively, it seems clear that introducing a substitute for petroleum should diversify the potential sources of liquid fuels supplies, increase the price elasticity of demand for petroleum, and thereby weaken the market power of an oil cartel such as OPEC. This seemingly obvious conclusion becomes clouded when one recognizes that not only may OPEC members themselves produce GT-L's, but they may be dominant producers of the substitute fuel due to their extensive, unutilized gas resources. The economic theory of a monopolistic cartel producing two substitute commodities is presented in the appendix. The equations are far more complex than the simple von Stackelberg model, and are also ambiguous, the conclusion depending on the specific values of key parameters. Although it appears that under most circumstances, theory indicates that the existence of a G-T-L industry will increase competitiveness in world liquid fuels markets, it is perhaps useful to illustrate the theoretical results with a simple simulation model. While the results of the simulation model depend on the specific parameter values assumed, to the extent that reasonable values are used, the simulation can increase confidence in and the same time clarify the theoretical conclusions.

We construct a simple simulation model of a world petroleum and G-T-L market, based on the Energy Information Administration's 1999 Annual Energy Outlook (AEO) Reference Case Forecast (U.S. DOE/EIA, 1998e). The model is comprised of three equations:

1. World liquid fuels demand

2. Rest-of-World (non-OPEC) petroleum supply, and

3. Rest-of-World G-T-L supply.

Both petroleum supply and G-T-L supply by OPEC are specified by assumption (exogenously). Supply and demand equations are assumed to be linear, and have the lagged adjustment form. The petroleum equations are calibrated to the 1999 AEO Reference Case by assuming elasticities of supply and demand for the base year of 1997 and the lagged adjustment rate, and then calculating the price slope and intercept coefficients that fit 1997 price and quantity data. The assumed short-run elasticity of demand for 1997 is -0.04 . The assumed short-run elasticity of supply is +0.04 . $^{6}$ Note that the elasticities in the linear form are not constant; at $\$ 40 / \mathrm{bbl}$ they would be approximately twice as large. The assumed lagged adjustment parameters of 0.9 for both supply and demand imply that long-run elasticities will be 10 times the short-run elasticities. Quantities are in millions of barrels per day (mmbd) of petroleum ${ }^{7}$ and prices in 1997 \$ per barrel of crude oil. The resulting equations for 1997 are as follows:

1997 World Petroleum Demand:

\footnotetext{
${ }^{6}$ These values are broadly consistent with the economic literature on petroleum supply and demand. Please see, e.g., Huntington (1991), Gately (1995).

7“Petroleum" includes crude oil, lease condensate, natural gas plant liquids, other hydrocarbons, hydrogen and other refinery feedstocks, as well as refinery gain. This definition is very close to total liquid fuels supply.
} 


$$
{ }^{\mathrm{d}} \mathrm{Q}_{\mathrm{t}}=12.408-0.159 \cdot \mathrm{P}_{\mathrm{t}}+0.9 \cdot \mathrm{Q}_{\mathrm{t}-1}
$$

1997 ROW Petroleum Supply:

$$
{ }^{\mathrm{s}} \mathrm{q}_{\mathrm{t}}=3.230+0.0947 \cdot \mathrm{P}_{\mathrm{t}}+0.9 \cdot \mathrm{q}_{\mathrm{t}-1}
$$

These equations are calibrated to future forecast years by calculating year-specific constant terms such that supply and demand exactly balance at the forecasted prices and given the forecasted levels of OPEC production. These adjusted constants reflect growth in income, technological changes and other non-price factors incorporated in the 1999 AEO forecast.

A linear "rest-of-world" (ROW) G-T-L supply curve was constructed by assuming that 1.25 tcf of natural gas could be available for G-T-L production at $\$ 0.50 / \mathrm{mcf}$, and $3.75 \mathrm{tcf}$ at $\$ 1 / \mathrm{mcf}$. These two points imply that $0.342 \mathrm{mmbd}$ of G-T-L's could be produced at $\$ 16 / \mathrm{bbl}$ and $1.03 \mathrm{mmbd}$ at \$21/bbl., using optimistic assumptions about G-T-L production costs, as described above in section 4 . The two points, together with an assumed lagged adjustment rate, define a linear, lagged adjustment supply curve for ROW G-T-L production.

ROW G-T-L supply curve:

$$
\mathrm{g}_{\mathrm{t}}=-2.620+0.137 \cdot \mathrm{P}_{\mathrm{t}}+0.9 \cdot \mathrm{g}_{\mathrm{t}-1}
$$

World liquid fuels supply is assumed to be the sum of OPEC and ROW petroleum and G-T-L production. This implies that G-T-L's and petroleum are perfect substitutes. In fact, G-T-L products are superior to crude oil and more like refined products. Since they are extremely close, but not perfect substitutes, this simplifying assumption should have little impact on the conclusions of the simulation.

Scenarios were created from the 1999 AEO Reference Case by adding ROW or OPEC G-T-L production, or changing OPEC oil production. Any of these changes creates a disequilibrium, so that petroleum supply and demand will not balance at the Reference Case prices. A new set of prices that do equilibrate supply and demand is computed to create a new market equilibrium scenario. ${ }^{8}$ The energy security implications of a scenario are represented by the change in world oil prices, and the changes in OPEC revenues and profits. The distinction between revenues and profits is important, since the profit per barrel of G-T-L's for OPEC will be much smaller than the profit margin for oil. As a result, a one-for-one substitution of a barrel of G-T-L production for a barrel of oil production will reduce OPEC's profits. This is both a theoretically (see appendix) and empirically significant factor in the energy security implications of G-T-L's. The significance of G-T-L's greater capital intensiveness derives not so much from the sunk costs invested in G-T$\mathrm{L}$ production, as from the smaller profit margins it offers to a producer with market power.

\footnotetext{
${ }^{8}$ The simulation model was set up as an $\operatorname{Excel}(\mathrm{TM})$ spreadsheet, and prices were determined by minimizing the squared deviations of supply and demand, using the spreadsheet's Solver(TM) algorithm.
} 
Three new scenarios were created:

(1) Only ROW G-T-L production

(2) Only OPEC G-T-L production

(3) ROW and OPEC G-T-L production

Results are summarized in Table 12.

The ROW G-T-L scenario assumes that non-OPEC G-T-L production begins in 2005. To avoid negative values, an initial, non-zero "lagged supply" number must be provided to the first year's supply equation. The value used was $0.2 \mathrm{mmbd}$. Supply is then allowed to increase in accordance with petroleum prices and the lagged adjustment model. ROW G-T-L output begins at $0.1 \mathrm{mmbd}$ in 2005 (about five 20,000 bpd plants or a smaller number of larger plants) and increases gradually to $1.3 \mathrm{mmbd}$ by 2020 . This is only a little more than 1 percent of the total global liquid fuels demand of $115 \mathrm{mmbd}$ in 2020. In the OPEC G-T-L scenario, it is assumed that OPEC produces the same amount of G-T-L's in each year as the ROW producers do in the ROW G-T-L scenario. In the ROW and OPEC G-T-L scenario, OPEC produces the same amount as in the OPEC G-T-L scenario, but ROW production follows market prices. Combined OPEC and ROW G-T-L production begins at $0.2 \mathrm{mmbd}$ in 2005 and increases gradually to $2.3 \mathrm{mmbd}$ in 2020, 2 percent of global liquid fuels supply. OPEC supplies $1.3 \mathrm{mmbd}$, ROW producers 1.0 mmbd. OPEC petroleum production remains unchanged from the Reference Case in all of the above scenarios, by assumption.

Four liquid fuels supply curtailment scenarios were created by assuming a sudden cutback in OPEC petroleum production in 2015, in each of the three scenarios and the Reference Case. The curtailment is initially 10 percent of OPEC's combined petroleum and G-T-L production, drops to 7.5 percent in 2017, 6.7 percent in 2018, and 5 percent for 2019 and 2020.

In all three scenarios, the introduction of G-T-L production reduces world oil prices and cuts OPEC profits, assuming OPEC continues producing oil at the same rate as in the Reference Case. The price decrease is not large, $\$ 0.26 / \mathrm{bbl}$ in 2006 in the ROW \& OPEC G-T-L scenario, increasing to $\$ 1.41$ by 2020 (Figure 9), a 6 percent reduction in price versus the Reference Case as a result of the substitution of G-T-L's for 2 percent of the world's oil supply. Of course, this price reduction is dependent on the assumption that OPEC continues to produce oil at the same level as in the Reference Case.

The simulations indicate that OPEC would suffer a loss of profit versus the Reference Case even if it produced G-T-L's and the ROW did not. One reason for this result is that the profit margin on G-T-L's is much smaller than on oil. Whereas we assume OPEC can produce a barrel of oil 
Table 12. Gas-to-Liquids Simulation Model Results for Eight Scenarios

\begin{tabular}{|c|c|c|c|c|c|c|c|c|c|c|c|c|}
\hline & $\begin{array}{c}\text { Petroleum } \\
\text { Supply } \\
\text { mmbd }\end{array}$ & $\begin{array}{l}\text { Solution } \\
\text { Price } \\
1997 \$ / \text { bbl }\end{array}$ & $\begin{array}{c}\text { OPEC } \\
\text { Petroleum } \\
\text { mmbd }\end{array}$ & $\begin{array}{l}\text { OPEC } \\
\text { G-T-L } \\
\text { mmbd }\end{array}$ & $\begin{array}{c}\text { ROW Oil } \\
\text { Supply } \\
\text { mmbd }\end{array}$ & $\begin{array}{l}\text { ROW } \\
\text { G-T-L } \\
\text { mmbd }\end{array}$ & $\begin{array}{c}\text { Petroleum } \\
\text { Supply } \\
\text { mmbd }\end{array}$ & $\begin{array}{l}\text { Solution } \\
\text { Price } \\
1997 \$ / b b l\end{array}$ & $\begin{array}{c}\text { OPEC } \\
\text { Petroleum } \\
\text { mmbd }\end{array}$ & $\begin{array}{l}\text { OPEC } \\
\text { G-T-L } \\
\text { mmbd }\end{array}$ & $\begin{array}{c}\text { ROW Oil } \\
\text { Supply } \\
\text { mmbd }\end{array}$ & $\begin{array}{l}\text { ROW } \\
\text { G-T-L } \\
\text { mmbd }\end{array}$ \\
\hline Year & \multicolumn{6}{|c|}{1999 AEO Reference Case } & \multicolumn{6}{|c|}{ ROW G-T-L Scenario } \\
\hline 2000 & 77.17 & $\$ 13.97$ & 30.27 & 0.00 & 46.90 & 0.00 & 77.17 & $\$ 13.97$ & 30.27 & 0.00 & 46.90 & 0.00 \\
\hline 2005 & 87.06 & $\$ 19.25$ & 35.60 & 0.00 & 51.46 & 0.00 & 87.13 & $\$ 18.82$ & 35.60 & 0.00 & 51.42 & 0.11 \\
\hline 2010 & 95.28 & $\$ 21.29$ & 40.35 & 0.00 & 54.93 & 0.00 & 95.59 & $\$ 20.68$ & 40.35 & 0.00 & 54.74 & 0.50 \\
\hline 2015 & 104.17 & $\$ 21.91$ & 48.70 & 0.00 & 55.47 & 0.00 & 104.76 & $\$ 21.26$ & 48.70 & 0.00 & 55.12 & 0.94 \\
\hline \multirow[t]{2}{*}{2020} & 114.41 & $\$ 22.73$ & 58.81 & 0.00 & 55.60 & 0.00 & 115.24 & $\$ 21.95$ & 58.81 & 0.00 & 55.11 & 1.32 \\
\hline & \multicolumn{6}{|c|}{ OPEC G-T-L Scenario } & \multicolumn{6}{|c|}{ ROW \& OPEC G-T-L Scenario } \\
\hline 2000 & 77.17 & $\$ 13.97$ & 30.27 & 0.00 & 46.90 & 0.00 & 77.17 & $\$ 13.97$ & 30.27 & 0.00 & 46.90 & 0.00 \\
\hline 2005 & 87.13 & $\$ 18.82$ & 35.60 & 0.11 & 51.42 & 0.00 & 87.17 & $\$ 18.55$ & 35.60 & 0.11 & 51.39 & 0.07 \\
\hline 2010 & 95.59 & $\$ 20.68$ & 40.35 & 0.50 & 54.74 & 0.00 & 95.81 & $\$ 20.24$ & 40.35 & 0.50 & 54.61 & 0.35 \\
\hline 2015 & 104.76 & $\$ 21.27$ & 48.70 & 0.94 & 55.12 & 0.00 & 105.21 & $\$ 20.77$ & 48.70 & 0.94 & 54.85 & 0.71 \\
\hline \multirow[t]{2}{*}{2020} & 115.24 & $\$ 21.94$ & 58.81 & 1.32 & 55.11 & 0.00 & 115.88 & $\$ 21.32$ & 58.81 & 1.32 & 54.73 & 1.02 \\
\hline & \multicolumn{6}{|c|}{ Supply Shock 1999 AEO Reference Case } & \multicolumn{6}{|c|}{ Supply Shock ROW G-T-L } \\
\hline 2000 & 77.17 & $\$ 13.97$ & 30.27 & 0.00 & 46.90 & 0.00 & 77.17 & $\$ 13.97$ & 30.27 & 0.00 & 46.90 & 0.00 \\
\hline 2005 & 87.06 & $\$ 19.25$ & 35.60 & 0.00 & 51.46 & 0.00 & 87.13 & $\$ 18.83$ & 35.60 & 0.00 & 51.42 & 0.11 \\
\hline 2010 & 95.28 & $\$ 21.31$ & 40.35 & 0.00 & 54.93 & 0.00 & 95.59 & $\$ 20.68$ & 40.35 & 0.00 & 54.74 & 0.50 \\
\hline 2015 & 101.12 & $\$ 41.09$ & 48.70 & 0.00 & 57.29 & 0.00 & 102.78 & $\$ 33.73$ & 48.70 & 0.00 & 56.30 & 2.65 \\
\hline \multirow[t]{2}{*}{2020} & 112.57 & $\$ 24.25$ & 58.81 & 0.00 & 56.70 & 0.00 & 113.76 & $\$ 23.14$ & 58.81 & 0.00 & 55.98 & 1.91 \\
\hline & \multicolumn{6}{|c|}{ Supply Shock OPEC G-T-L } & \multicolumn{6}{|c|}{ Supply Shock ROW \& OPEC G-T-L } \\
\hline 2000 & 77.17 & $\$ 13.97$ & 30.27 & 0.00 & 46.90 & 0.00 & 77.17 & $\$ 13.97$ & 30.27 & 0.00 & 46.90 & 0.00 \\
\hline 2005 & 87.13 & $\$ 18.82$ & 35.60 & 0.11 & 51.42 & 0.00 & 87.17 & $\$ 18.54$ & 35.60 & 0.11 & 51.39 & 0.07 \\
\hline 2010 & 95.59 & $\$ 20.68$ & 40.35 & 0.50 & 54.74 & 0.00 & 95.81 & $\$ 20.24$ & 40.35 & 0.50 & 54.61 & 0.35 \\
\hline 2015 & 102.61 & $\$ 34.77$ & 48.70 & 2.65 & 56.40 & 0.00 & 103.81 & $\$ 29.54$ & 48.70 & 2.65 & 55.68 & 1.91 \\
\hline 2020 & 113.70 & $\$ 23.20$ & 58.81 & 1.91 & 56.02 & 0.00 & 114.67 & $\$ 22.33$ & 58.81 & 1.91 & 55.45 & 1.54 \\
\hline
\end{tabular}


Figure 9. Estimated Oil Prices In G-T-L Scenarios

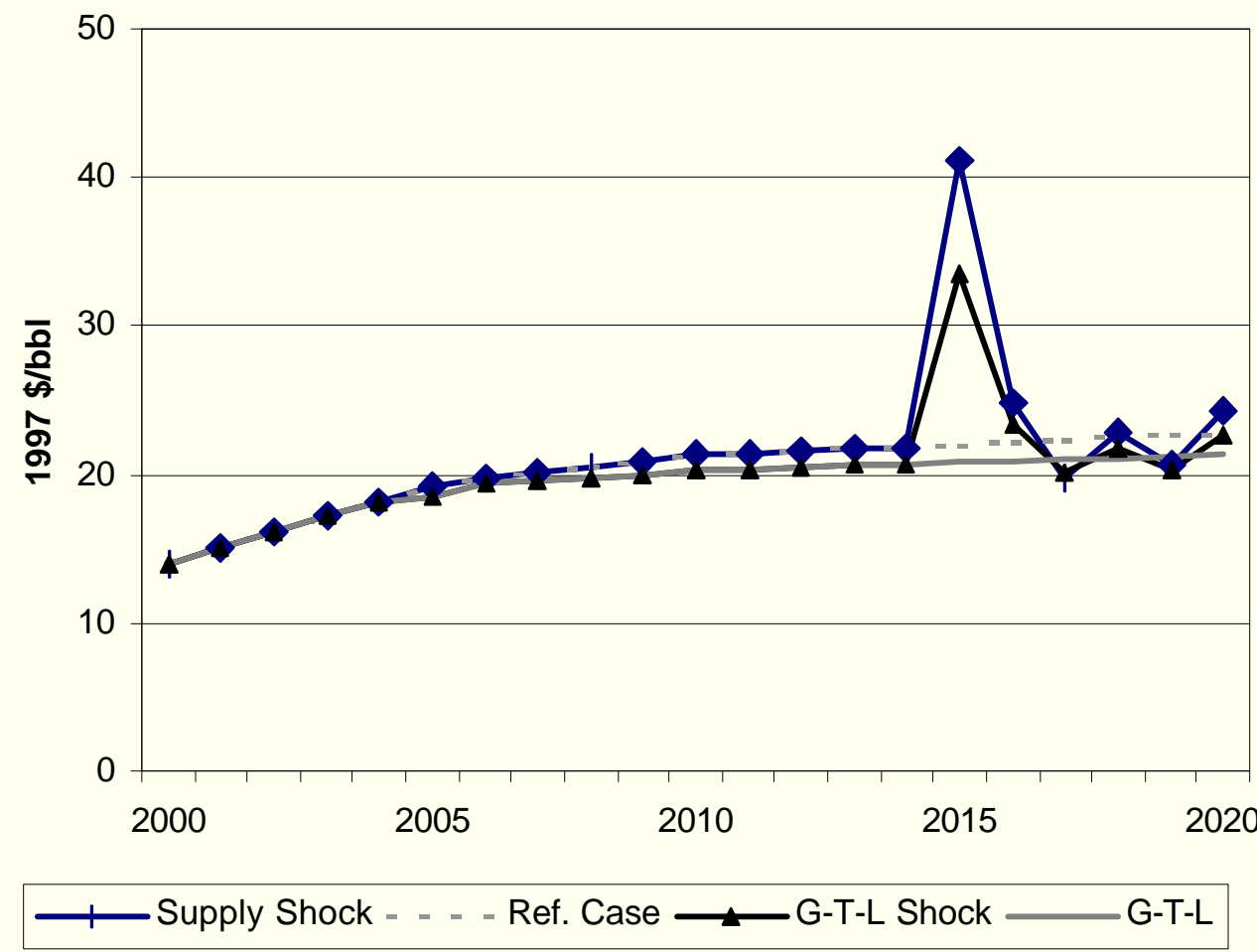

for $\$ 4$, a barrel of G-T-L costs $\$ 11$ (these costs exclude the value of the resources produced). Thus, OPEC loses $\$ 7 / \mathrm{bbl}$ by shifting a barrel of output from oil to G-T-L. As a result, even though OPEC's share of the liquid fuels market and its total output increase in the OPEC G-T-L scenario, OPEC's total profits decline by almost as much as they do when only ROW sources supply G-T-L's. Again, these results depend on the assumption that OPEC maintains the Reference Case level of oil output. The implication is that producing G-T-L's may not be in OPEC's economic interest. However, this does not mean it is against the economic interests of a particular OPEC member. A state like Qatar, with vast resources of natural gas but much less oil might certainly find it in its individual economic interest to begin G-T-L production. However, this action would tend to weaken the position of OPEC as a whole. Increasing the divergence of interests within OPEC would be an added energy security advantage not accounted for in these simple simulations.

While the supply curtailment proves profitable for OPEC under all scenarios, the existence of a GT-L industry reduces the profits from an oil price shock in all cases. An oil supply shock in 2015 in the Reference Case increases OPEC profits through 2020 by $\$ 157$ billion. Although OPEC output is reduced by 10 percent in 2015 , the price of oil jumps from $\$ 21 / \mathrm{bbl}$ to $\$ 41 / \mathrm{bbl}$, more than 
making up for revenue lost on reduced oil sales (Figure 9). Prices fall after 2016, reaching $\$ 24.25 / \mathrm{bbl}$ in 2020 , versus $\$ 22.73$ in the reference case. OPEC profits are higher in every price shock case than in the comparable case without a supply shock. The existence of an ROW G-T-L industry reduces the benefit of a supply shock from $\$ 157$ billion to $\$ 95$ billion. If OPEC itself is producing G-T-L's the benefit of a shock is smaller still, $\$ 79$ billion.

Table 13. Simulations of G-T-L Impacts on OPEC Revenues and Profits

\begin{tabular}{lccc}
\hline Scenario & $\begin{array}{c}\text { OPEC Revenues } \\
\text { Billion 1997 \$ }\end{array}$ & $\begin{array}{c}\text { OPEC Profits } \\
\text { Billion 1997\$ }\end{array}$ & $\begin{array}{c}\text { Change in Profit } \\
\text { versus Reference } \\
\text { Billion 1997 \$ }\end{array}$ \\
\hline Reference Case & 7,237 & 5,806 & 0 \\
ROW G-T-L & 7,079 & 5,647 & -159 \\
OPEC G-T-L & 7,167 & 5,690 & -116 \\
ROW \& OPEC G-T-L & 7,044 & 5,567 & -239 \\
\hline
\end{tabular}

Table 14. Simulation of G-T-L Impacts Combined with an Oil Supply Shock

\begin{tabular}{lccc}
\hline Scenario & $\begin{array}{c}\text { OPEC Revenues } \\
\text { Billion 1997 \$ }\end{array}$ & $\begin{array}{c}\text { OPEC Profits } \\
\text { Billion 1997\$ }\end{array}$ & $\begin{array}{c}\text { Change in Profit } \\
\text { versus no Shock } \\
\text { Billion 1997 \$ }\end{array}$ \\
\hline Reference Case & 7,360 & 5,963 & +157 \\
ROW G-T-L & 7,139 & 5,742 & +95 \\
OPEC G-T-L & 7,295 & 5,827 & +137 \\
ROW \& OPEC G-T-L & 7,114 & 5,646 & +79 \\
\hline
\end{tabular}

These simulations illustrate the potential impacts of G-T-L's on world liquid fuels markets, subject to a number of assumptions. Although the parameters for the analysis are intended to be plausible, other reasonable values might also be chosen. The results are also influenced by key assumptions about how OPEC might respond to development of G-T-L's and the degree of substitutability between G-T-L's, petroleum and other liquid fuel resources. Still, the results of the simulations, in addition to the theoretical analysis presented in the appendix, strongly indicate that the development of even a modest quantity of G-T-L supply would be beneficial to world liquid fuel markets by exerting downward pressure on oil prices, mitigating the potential impacts of oil supply disruptions and reducing the economic incentive for such disruptions. These results appear to hold whether or not OPEC itself is a major supplier of G-T-L's. 


\section{CRITICAL ISSUES IN THE FUTURE OF G-T-L'S}

The future market for middle distillate transportation fuels from natural gas will depend on four key factors:

- the impacts of environmental regulations on refinery operations and costs,

- the world supply curve for low-cost natural gas,

- further advances in G-T-L technology, and

- the fuel-cycle greenhouse gas consequences of G-T-L use.

The energy security implications for the United States will depend primarily on the potential supply of low-cost natural gas outside of the OPEC states. There is no doubt that very significant quantities of gas that could be used to produce liquid fuels exist in the form of vented or flared, re-injected, and stranded associated and non-associated natural gas. Precisely how much will be available at what price, and where, has yet to be determined. Studies now underway by the petroleum consulting industry may or may not provide the necessary data to analyze how an emerging G-T-L industry would change world liquid fuels markets and U.S. energy security.

There are reasons to believe that a new G-T-L industry would significantly increase competitiveness in world energy markets, but there are also factors that could make its impact small. Economic theory indicates that the greater capital intensiveness of G-T-L production in comparison to petroleum production favors a more competitive liquid fuels market. The potential availability of large quantities of gas from flaring, venting and re-injection also suggests that there might be a large number of competitive feedstock sources. On the other hand, the estimated combined 70 percent share of stranded gas reserves belonging to OPEC states and Russia, and in particular the likely low cost of producing stranded gas in the Middle East, suggest that a few nations might also dominate the supply of G-T-L feedstocks. While theory and a simple simulation analysis suggest that there would always be some benefits to the emergence of a G-T-L alternative to petroleum, whether those benefits would or would not be significant is a question that can be answered only by more detailed empirical analysis.

At first glance, it appears that G-T-L distillates would have higher full fuel cycle GHG emissions that petroleum derived diesel. But on closer examination, this conclusion turns out to depend on three factors:

- the precise source of the natural gas feedstock,

- whether comparison is made to a diesel or a gasoline-powered vehicle, and

- whether it is assumed that carbon emissions from the conversion process are sequestered or released. 
If the feedstock for G-T-L conversion is gas that would otherwise have been flared, then conversion of gas to distillate fuel would reduce GHG emissions by an amount roughly equal to the total fuel cycle emissions of the petroleum-based diesel fuel displaced. If the feedstock would have been vented, there would be an additional benefit due to the much higher global warming potential of methane in comparison to carbon dioxide. On the other hand, if the gas would otherwise have been left in the ground or re-injected, then the energy losses in conversion to liquid fuels would probably increase fuel cycle GHG emissions, unless the $\mathrm{CO}_{2}$ produced in conversion were sequestered. Sequestration may be feasible but it will add to the cost of G-T-L production, except perhaps if the feedstock is coal seam gas. Until an integrated evaluation of production, conversion, and sequestration is carried out for a variety of potential gas sources, whether or not G-T-L's will increase or decrease GHG emissions will be an open question.

Finally, available data suggest that a diesel vehicle powered by 20 percent F-T diesel would create 4.5 percent more fuel cycle $\mathrm{CO}_{2}$ emissions than a vehicle powered by conventional diesel, but 3.9 percent less than a comparable gasoline vehicle. The difference is due to the greater efficiency of diesels versus gasoline vehicles. The comparison to gasoline emissions is invalid, however, unless the 20 percent F-T blend is necessary to enable diesel vehicles to meet criteria pollutant emissions standards. Even then, the case would have to be made that the 20 percent blend enabled a displacement of what would otherwise have been a gasoline vehicle.

Each of these unknown factors is susceptible to analysis. Further analysis of this subject in the following areas is recommended.

1. If data are not available from existing sources, conduct a comprehensive study to estimate the world supply curve of natural gas for G-T-L conversion, by nation.

2. Conduct a study of the refinery impacts of reformulated diesel fuel and derive refinery demand curves for F-T distillates. (This study has already initiated by the U.S. DOE.)

3. Develop a modeling framework to quantitatively assess the world liquid fuels market impacts of a G-T-L industry. Relatively minor modifications to DOE's existing models could probably accomplish this.

4. Conduct an integrated assessment of the GHG and cost implications of alternative G-T-L production and $\mathrm{CO}_{2}$ sequestration alternatives.

5. Using the above, conduct an integrated assessment of the energy security and environmental costs and benefits of a global G-T-L industry at various scales. 
The benefits of G-T-L's for diesel pollutant emissions and energy security may or may not be outweighed by higher costs and possibly higher (or lower) GHG emissions. This study may have resolved some issues and raised others. It seems clear, however, that the possible benefits of G-T-L's merit further development of G-T-L technologies and more detailed analysis of their costs and benefits. 


\section{REFERENCES}

1. Adelman, M.A. 1990. "The 1990 Oil Shock Is Like All the Others," The Energy Journal, vol. 11, no. 4, pp. 1-13.

2. ARCO. 1997. "ARCO, Syntroleum Begin Joint Development of Synfuels Reactor Technology," http://www.araco.com/corporate/news/p102497.htm , October 24, 1997.

3. Banks, F.E. 1986. "Economic Theory and the Price of Oil," OPEC Review, vol. 10, no. 3, pp. 321-334.

4. Bertoli, C., N. Del Giacomo, and C. Beatrice. 1997. "Diesel Combustion Improvements by the Use of Oxygenated Synthetic Fuels," SAE Technical Paper 972972, pp. 23-34 in, Alternative Fuels Technology and Developments, SP-1298, Society of Automotive Engineers, Warrendale, Pennsylvania.

5. Campbell, C.J. and J.H. Laherrère. 1998. "The End of Cheap Oil," Scientific American, vol. 278, no. 1, pp. 78-83, March.

6. Choi, C.Y., G.R. Bower, and R.D. Reitz. 1997. "Effects of Biodiesel Blended Fuels and Multiple Injections on D.I. Diesel Engines," SAE Technical Paper 970218, pp. 1-20, in Alternative Fuels and Heavy Duty Engines, SP-1247, Society of Automotive Engineers, Warrendale, Pennsylvania.

7. Corke, M.J. 1998a. "G-T-L Technologies Focus on Lowering Costs," Oil and Gas Journal, vol. 96, no. 38, pp. 71-77.

8. Corke, M.J. 1998b. "Economics Favor GTL Projects with Condensate Coproduction," Oil \& Gas Journal, vol. 96, no. 39, pp. 96-101, September 28.

9. Davis, S.C. 1998. Transportation Energy Data Book, Edition 18, ORNL-6941, Oak Ridge National Laboratory, Oak Ridge, Tennessee.

10. Delucchi, M.A. 1998. Lifecycle Energy Greenhouse-Gas Emissions, and Air Pollution from Use of Transportation Fuels and Electricity, Institute of Transportation Studies, University of California, Davis, CA, February, 1998.

11. Duleep, K.G. 1998. "Emissions Benefits of Fischer-Tropsch Diesel," presentation to Office of Transportation Technologies, U.S. Department of Energy, May 6, 1998, Energy and Environmental Analysis, Inc., Arlington, Virginia.

12. Energy and Environmental Analysis, Inc. 1998. "Fuel Supply Database Documentation Fuel Strategy Database Development Project," Arlington, Virginia, April 23, 1998.

13. Energy and Environmental Analysis, Inc. 1993. "Development Costs of Undeveloped Nonassociated Gas Reserves in Selected Countries," DOE/EP-003P, Technical Report Nine, Assessment of Costs and Benefits of Flexible and Alternative Fuel Use in the U.S. Transportation Sector, United Stated Department of Energy, Office of Domestic and International Policy, Washington, DC.

14. Fagan, M.N. 1997. "Resource Depletion and Technical Change: Effects on U.S. Crude Oil Finding Costs from 1977 to 1994," The Energy Journal, vol. 18, no. 4, pp. 91-105.

15. Financial Times. 1997. "Gas into Liquid Gold," Friday, July 4, 1997. 
16. Fouda, S.A. 1998. "Liquid Fuels from Natural Gas," Scientific American, vol. 278, no. 3, pp. 92-95.

17. Gately, D. 1995. “Strategies for OPEC's Pricing and Output Decisions," The Energy Journal, vol. 16, no. 3, pp. 1-38.

18. Georgiou, Angela. 1998. Personal communication, Arthur D. Little of Canada Limited, October 20, 1998.

19. Gerini, A. and X Montagne. 1997. "Automotive Direct Injection Diesel Sensitivity to Diesel Fuel Characteristics," SAE Technical Paper 972963, pp. 45-56 in, Combustion \& Emissions in Diesel Engines, SP-1299, Society of Automotive Engineers, Warrendale, Pennsylvania.

20. Gordon, R.L. 1994. "Energy, Exhaustion, Environmentalism, and Etatism," The Energy Journal, vol. 15, no. 1, pp. 1-16.

21. Greene, D.L. 1997. "Oil Dependence: The Value of R\&D," Proceedings of the Thirty Second Intersociety Energy Conversion Engineering Conference, vol. 3, pp. 2148-2153, American Institute of Chemical Engineers, New York.

22. Greene, D.L. and P.N. Leiby. 1993. The Social Costs to the U.S. of Monopolization of the World Oil Market, 1972-1991, ORNL-6744, Oak Ridge National Laboratory, Oak Ridge, TN, March.

23. Greene, D.L., D.W. Jones and P.N. Leiby. 1998. "The Outlook for U.S. Oil Dependence," Energy Policy, vol. 26, no. 1, pp. 55-69.

24. Herzog, H., E. Drake, and E. Adams. 1997. " $\mathrm{CO}_{2}$ Capture, Reuse, and Storage Technologies for Mitigating Global Climate Change," DOE Order No. DE-AF2296PC01257, Energy Laboratory, Massachusetts Institute of Technology, Cambridge, MA, January.

25. Huntington, H.G. 1991. "Inferred Demand and Supply Elasticities from a Comparison of World Oil Models," EMF WP 11.5, Energy Modeling Forum, Stanford University, Stanford, California, January.

26. Ivanhoe, L.F. and G.C. Leckie. 1993. "Global Oil, Gas Fields, Sizes Tallied, Analyzed," Oil and Gas Journal, vol. 91, no. 7, pp. 87-91.

27. Jepma, C.J., A. Asaduzzaman, I. Mintzer, R.S. Maya, and M. Al-Moneef. 1996. “A Generic Assessment of Response Options," pp. 225-262 in, J.P. Bruce, H. Lee, and E.F. Haites, eds., Climate Change 1995: Economic and Social Dimensions of Climate Change, Cambridge University Press, Cambridge, England.

28. Kerr, R.A. 1998. "The Next Oil Crisis Looms Large - and Perhaps Close," Science, vol. 281, pp. 1128-1131, August 21.

29. Li, X., W.L. Chippior, and O.L. Gülder. 1997. "Effects of Cetane Enhancing Additives and Ignition Quality on Diesel Engine Emissions," SAE Technical Paper 972968, pp. 125-136 in, Combustion \& Emissions in Diesel Engines, SP-1299, Society of Automotive Engineers, Warrendale, Pennsylvania.

30. Mabro, R. 1992. "OPEC and the Price of Oil," The Energy Journal, vol 13, no. 2, pp. $1-17$.

31. Mark, J. and C. Morey. 1999. "Diesel Passenger Vehicles and the Environment," Union of Concerned Scientists, Berkeley, California, April. 
32. Martin, B., P. Aakko, D. Beckman, N. Del Giacomo, and F. Giavazzi. 1997. "Influence of Future Fuel Formulations on Diesel Engine Emissions - A Joint European Study," SAE Technical Paper 972966, pp. 97-109 in, Combustion \& Emissions in Diesel Engines, SP1299, Society of Automotive Engineers, Warrendale, Pennsylvania.

33. Masters, C.D., E.D. Attanasi, and D.H. Root. 1994. "World Petroleum Assessment and Analysis," Proceedings of the $14^{\text {th }}$ World Petroleum Congress, John Wiley and Sons, New York.

34. McMillian, M.H. and M. Gautam. 1998. "Consideration for Fischer-Tropsch Derived Liquid Fuels as a Fuel Injection Emisson Control Parameter," SAE Technical Paper 982489, Society of Automotive Engineers, Warrendale, Pennsylvania.

35. McNutt, B. and G. Hadder. 1999. "Light Duty Diesel Fuel: U.S. Refinery Production and Distribution System Capability," manuscript, Office of Policy, U.S. Department of Energy, Washington, DC.

36. Norton, P., K. Vertin, B. Bailey, N.N. Clark, D.W. Lyons, S. Goguen and J. Everhardt. 1998. "Emissions from Trucks using Fischer-Tropsch Diesel Fuel," SAE Technical Paper 982526, Society of Automotive Engineers, Warrendale, Pennsylvania.

37. Oil \& Gas Journal. 1997. "Gas-to-liquids Projects Gaining Momentum as Process List Grows," PennWell Publishing Co., June 23, 1997.

38. Orr, L. 1998. " $\mathrm{CO}_{2}$ Sequestration: Deep Ocean, Acquifers and Oil Fields," presentation to Laboratory Energy R \& D Working Group, Washington, DC, November 12, 1998, School of Earth Sciences, Stanford University.

39. Parson, E.A. and D.W. Keith. 1998. "Fossil Fuels Without $\mathrm{CO}_{2}$ Emissions," Science, vol. 282, pp. 1053-1054, November 6, 1998.

40. PennWell Publishing Co. 1998. International Petroleum Encyclopedia,

41. Petroleum Economist. 1997. "Success Is What Your Catalyst Is Made Of," Petroleum Economist, vol. 64, no. 6, pp. 40-42.

42. Pintz, W.S. 1997. "Economical Conversion of Natural Gas to Liquid Synthetic Fuels: The Next Megatrend?" Energy Advisory, Number 192, East-West Center, Honolulu, January 15.

43. Remote Gas Strategies. 1999a. "ARCO Pilot Plant Begins Testing Syntroleum Technology," vol. III, no. 8, p.1, Zeus Development Corporation, Houston, Texas, August.

44. Remote Gas Strategies. 1999b. "New Air Separation Unit, Gas Supply Contracts Signed for Shell Bintulu Plant," vol III, no. 1, p. 2, July.

45. Remote Gas Strategies. 1999c. "Sasol, Chevron Forum Global Alliance for GTL Projects," vol. III, no. 1, p. 1, July.

46. Remote Gas Strategies. 1999d. "45-Month Phase Out of MTBE in California Will Impact Methanol Market," vol. III, no. 4, p. 8, April.

47. Remote Gas Strategies. 1999e. "Hydates-to-Gas-Liquids Patent Issued; 10,000-bpd Sweetwater Plant in 2000," vol. III, no. 10, p. 2, October.

48. Remote Gas Strategies. 1998. "Chevron and Sasol Announce Plans for 20,000-bpd GTL Plant in Nigeria," www.remotegasstrategies.com/980501ch.html , May, 1998.

49. Rentech, Inc. 1998. Internet website, www.gastoliquids.com, October 19, 1998. 
50. Ryan, T.W. and D.A. Montalvo. 1997. "Emissions Performance of Fischer-Tropsch Diesel Fuels," Conference Paper: 1997 AIChE Spring Meeting, Houston, Texas, March 9-13, 1997.

51. Salameh, M.G. 1995. "Can Technology Provide the Answer to Future Oil Crises?” OPEC Review, Winter, pp. 293-305.

52. Saunders, B. 1998. "Coming Next: Natural Gas Refineries," Oil and Gas Investor, Hart Publications, Inc., Houston, Texas.

53. Schaberg, P.W., I.S. Myburgh, J.J. Botha, P.N. Roets, C.L. Viljoen, L.P. Dancuart, and M.E. Starr. 1997. "Diesel Exhaust Emissions Using Sasol Slurry Phase Distillate Process Fuels”, SAE Technical Paper 972898, Society of Automotive Engineers, Warrendale, Pennsylvania.

54. Socolow, R., ed. 1997. "Fuels Decarbonization and Carbon Sequestration: Report of a Workshop," PU/CEES Report No. 302, Center for Energy and Environmental Studies, Princeton University, Princeton, New Jersey, September, available on the internet at http://www.princeton.edu/ ceesdoe/ .

55. Syntroleum. 1998. "The Syntroleum Process," Syntroleum Corporation, Tulsa, Oklahoma.

56. Syntroleum. 1997. "Texaco, Brown \& Root and Syntroleum Sign Agreement to Pursue First Commercial Gas-to-Liquids Plant," press release, December 10, 1997, Tulsa, Oklahoma.

57. U.S. Department of Energy. 1999. Oil and Gas R\&D Programs, DOE/FE-0386, Office of Natural Gas and Petroleum Technology, Office of Fossil Energy, Washington, DC, April.

58. U.S. Department of Energy. 1991. National Energy Strategy, DOE/S-0082P, Washington, DC, February.

59. U.S. Department of Energy, Energy Information Administration. 1998a. Monthly Energy Review: November 1998, DOE/EIA-0035(98/11), Washington, DC.

60. U.S. Department of Energy, Energy Information Administration. 1998b. Annual Energy Review 1997, DOE/EIA-0384(97), Washington, DC.

61. U.S. Department of Energy, Energy Information Administration. 1998c. International Energy Outlook 1998, DOE/EIA-0484(98), Washington, DC.

62. U.S. Department of Energy, Energy Information Administration. 1998d. International Energy Annual 1996, DOE/EIA-0219(96), Washington, DC, February.

63. U. S. Department of Energy, Energy Information Administration. 1998e. Annual Energy Outlook 1999, DOE/EIA-0383(99), Washington, DC, December.

64. U.S. Department of Energy, Energy Information Administration. 1997a. "Worldwide Natural Gas Supply and Demand and the Outlook for Global LNG Trade," Natural Gas Monthly, Washington, DC, August.

65. U.S. Department of Energy, Energy Information Administration. 1997b. Alternatives to Traditional Transportation Fuels 1996, DOE/EIA-0585(96), Washington, DC.

66. U.S. Department of Energy, Fossil Energy. 1998a. "Gas-to-Liquids Conversion Technologies," www.fe.doe.gov/oil_gas/gastoliq.html , September 23, 1998.

67. U.S. Department of Energy, Fossil Energy. 1998b. "Sun Refining and Marketing's Gas-to-Liquids Project - Studying a Process that Mimics Nature," www.doe.gov/html/fe/sun.html, September 23. 
68. U.S. Department of Energy, Fossil Energy. 1998c. "Methane Hydrates," www.fe.doe.gov/oil_gas/methanehydrates/hydrates_intro.html, October 20.

69. U.S. Department of Energy, Federal Energy Technology Center, www.fetc.doe.gov/docs/review/unconv.html, July 14, 1999.

70. U.S. Department of Energy, Office of Policy. 1996. "Market Potential and Impacts of Alternative Fuel Use In Light-Duty Vehicles: A 2000/2010 Analysis,” DOE/PO-0042, Washington, DC, January.

71. U.S. Department of Transportation, Bureau of Transportation Statistics. 1997. Transportation Statistics Annual Report 1997, BTS97-S-01, Washington, DC.

72. U.S. Department of Transportation, Federal Highway Administration. 1997. Highway Statistics 1996, FHWA-PL-98-003, Washington, DC.

73. Walsh, M.P. 1998. “CAR Lines,” newsletter of Michael P. Walsh, consultant, Arlington, Virginia, mpwalsh@igc.apc.org, December, 1998.

74. Wang, M.Q. 1999. GREET 1.5 Transportation Fuel-Cycle Model, Volumes 1 and 2, ANL/ESD-39, Vol. 1 and Vol. 2, Center for Transportation Research, Argonne National Laboratory, Argonne, Illinois, August.

75. Watkins, G.C. 1992. "The Hotelling Principle: Autobahn or Cul-de-sac?" The Energy Journal, vol. 13, no. 1, pp. 1-24.

76. World Energy Council, International Institute for Applied Systems Analysis. 1995. Global Energy Perspectives to 2050 and Beyond, World Energy Council, London.

77. Zeus Development Corporation. 1998a. "Resources" available on the internet at http://www.remotegasstrategies.com/infrastructure.htm .

78. Zeus Development Corporation. 1998b. "Petroconsultants-MAI, Zeus Combine Upstream, Downstream Expertise for First Comprehensive Remote Gas Development Study," available at http://www.remotegasstrategies.com/981115pe.htm . 


\section{APPENDIX \\ VON STACKELBERG THEORY FOR SUBSTITUTE GOODS}

First, the case of a single monopolist producing two substitute goods is considered. Next, the existence of competitive producers in the von Stackelberg framework is recognized. Finally, the change in the world price elasticity of demand for oil due to the introduction of a new substitute is incorporated.

The existence of a substitute for crude oil adds a second product to the monopolists profit equation. Not only must the profit maximizing quantity of oil $\left(\mathrm{Q}_{\mathrm{o}}\right)$ be chosen to achieve an optimal oil price $\left(\mathrm{P}_{\mathrm{o}}\right)$, but the profit maximizing quantity $\left(\mathrm{Q}_{\mathrm{g}}\right)$ and price $\left(\mathrm{P}_{\mathrm{g}}\right)$ of gas must be also be selected.

$$
\Pi=\left(P_{o}-C_{o}\right) Q_{o}+\left(P_{g}-C_{g}\right) Q_{g}
$$

Again assuming that unit production costs are constant, and after appropriate manipulations, the first order condition for profit maximization leads to the following formula for the price of oil.

$$
P_{o}=\frac{C_{o}}{1+\frac{1}{\beta_{o}}\left[1+\alpha_{g o}\left\{\frac{P_{g} Q_{s}}{P_{o} Q_{o}}\left(1+\frac{1}{\beta_{g}}\right)-\frac{C_{g} Q_{s}}{P_{o} Q_{o}}\right\}\right]}
$$

Note that equation (7) is similar to equation (1), with the addition of the term in square brackets in the denominator. If that term is between 0 and 1 , it will reduce the effect of $1 / \hat{a}$, bringing market price $\left(\mathrm{P}_{\mathrm{o}}\right)$ closer to the cost of production. Clearly, this depends on whether the term beginning with $\hat{a}_{\mathrm{go}}$, the elasticity of gas liquid demand with respect to the price of oil, which itself is greater than 0 , is between 0 and -1 . In part, this depends on two ratios. The first is the ratio of G-T-L revenues $\left(\mathrm{P}_{\mathrm{g}} \mathrm{Q}_{\mathrm{g}}\right)$ to oil revenues $\left(\mathrm{P}_{\mathrm{o}} \mathrm{Q}_{\mathrm{o}}\right)$. The second is the ratio of the total cost of G-T-L production $\left(C_{g} Q_{g}\right)$ to crude oil revenues. If the G-T-L market were competitive, $P_{g} Q_{g}=C_{g} Q_{g}$, so the two ratios would be equal. Because the term in round brackets, $0<\left(1+1 / \hat{a}_{\mathrm{g}}\right)<1$, provided only that $\hat{a}_{\mathrm{g}}<-1$, the term to the right of $a_{\mathrm{go}}$ would in general be negative. For example, if $\hat{\mathrm{a}}_{\mathrm{g}}=-2$, then $(1+1 /(-2))=1 / 2$, and $\mathrm{P}_{\mathrm{g}}$ would have to be twice the cost of gas liquids production $\left(\mathrm{C}_{\mathrm{g}}\right)$, for the term not to be negative.

As a next step, competitive producers for both oil and G-T-L's are introduced in the von Stackelberg framework. Demand for the cartel's output is once again the net demand, after 
subtracting the quantity supplied by the ROW producers. This is true in both the crude oil and GT-L markets.

$$
Q_{o}=Q_{o}^{w}-q_{o} \quad ; \quad Q_{g}=Q_{g}^{w}-q_{g}
$$

In equation (8) the superscript $\mathrm{w}$ is used to indicate total world demand as opposed to the cartel's net demand. The new pricing formula can be obtained from equation (7) by substituting the net own and cross price elasticities into it, and interpreting the oil and G-T-L quantities as net demand for cartel output. The net demand elasticities depend on world market elasticities, as well as market shares and ROW supply response terms, analogously to equation (5).

$$
\frac{1}{b_{o}}=\frac{1}{b_{o}^{w}}\left(1+g_{o}\right) s_{o} \quad ; \quad a_{g o}=\frac{a_{g o}^{w}}{\left(1+g_{g}\right) s_{g}}
$$

If these terms are inserted into equation (7), a still more complicated pricing formula results.

$$
P_{o}=\frac{C_{o}}{1+\frac{1}{\beta_{o}{ }^{w}}\left(1+\gamma_{o}\right) \sigma_{o}\left[1+\frac{\alpha_{g o}^{w}}{\left(1+\gamma_{g}\right) \sigma_{g}}\left\{\frac{P_{g} Q_{g}}{P_{o} Q_{o}}\left(1+\frac{1}{\beta_{g}{ }^{w}}\left(1+\gamma_{g}\right) \sigma_{g}\right)-\frac{C_{g} Q_{g}}{P_{o} Q_{o}}\right\}\right]}
$$

Whether or not the price of oil will be lower under this formula than under the single-product von Stackelberg formula again depends on the large term in square brackets. While it cannot be guaranteed that this term will be smaller than 1, it is very likely to be. The following conditions make it more likely that oil prices will decrease:

1. The cost of G-T-L production $\mathrm{C}_{\mathrm{g}}$ is close to the price of G-T-L's, $\mathrm{P}_{\mathrm{g}}$.

2. Cartel market power is lower in the G-T-L market than in the oil market.

3. The ROW gas supply is elastic.

One more wrinkle must be added. G-T-L's are a new product, competing for the liquid fuels market with oil. Assuming the price elasticity of demand for liquid fuels does not change, the price elasticity of world crude oil demand will change because of the introduction of a new source of liquids. The new price elasticity of oil demand depends on the liquid fuels price elasticity (equal to the oil price elasticity when oil was the only fuel) according to the following formula.

$$
\beta_{o}^{w}=\beta_{l}{ }^{w} \frac{P_{o}}{P_{l}}-\alpha_{g o}{ }_{g o} \frac{Q_{g}^{w}}{Q_{o}^{w}}
$$


Equation (11) makes it clear that the world price elasticity of demand for oil will be greater with the introduction of a new source of liquid fuels, provided only that the new world price of liquid fuels is not significantly greater than the former price of oil. This follows from the fact that the cross price elasticity will be greater than zero (since G-T-L's and oil are substitutes). The larger the G-T-L market and the greater the degree of substitutability between fuels, the greater the increase in the price elasticity of oil demand.

Even after equation (11) is substituted into equation (10) there does not appear to be a way to mathematically demonstrate that the new price of oil can only be lower than that before G-T-L's were introduced. The reason is that the prices of oil and gas are simultaneously determined, and without knowing the price of G-T-L's we cannot be sure of the price of oil. However, if one substitutes the von Stackelberg monopoly formula for the price of gas in the absence of substitutability for oil (as an upper bound on the price of gas) into the oil price formula, then it can be shown that the price of oil will be lower than before G-T-L's became available, due entirely to the world price elasticity increase effect shown in equation (11). If one then substitutes the new lower price for oil in the gas pricing formula, the price of gas will fall below its von Stackelberg level. This iterative proof shows that the price of oil and the monopoly power of the cartel will both decline with the introduction of G-T-L's. 


\section{INTERNAL DISTRIBUTION}

1. MA. Brown

2. G.E. Courville

3. T.R. Curlee

4. S. Das

5. R.L. Graves

6-35. D.L. Greene

36. G.R. Hadder

37. P.S. Hu

38. R.M. Lee

39. P.N. Leiby
40. R.N. McGill

41. C.I. Moser

42. R.B. Shelton

43. R.E. Ziegler

44-45. Central Research Library

46.Document Reference Section

47.ORNL Patent Office

48-49. Laboratory Records

50. Laboratory Records-RC

\section{EXTERNAL DISTRIBUTION}

51. L.A. Abron, President, PEER Consultants, P.C., 1460 Gulf Blvd., $11^{\text {th }}$ Floor, Clearwater, Florida 34630

52. S.L. Cutter, Director, Hazards Research Lab, Department of Geography, University of South Carolina, Columbia, South Carolina 29208

53. S.G. Hildebrand, Director, Environmental Sciences Division, Oak Ridge National Laboratory, Post Office Box 2008, Oak Ridge, Tennessee 37831-6037

54. P.R. Rittelmann, FAIA, Executive Vice President, Burt Hill Kosar Rittelmann Associates, 400 Morgan Center, Butler, Pennsylvania 16001-5977

55. S.F. Tierney, The Economic Resource Group, Inc., One Mifflin Place, Cambridge, Massachusetts 02138

56. C.M. Walton, Ernest H.Cockrell Centennial Chair in Engineering and Chairman, Department of Civil Engineering, University of Texas at Austin, E. Cockrell, Jr. Hall I, Suite 4210, Austin, TX 78712-1075

57. OSTI, U.S. Department of Energy, P.O. Box 62, Oak Ridge, Tennessee 37831

58. Fred Abel, U.S. Department of Energy, PO-24, Room 7H-082, 1000 Independence Avenue, S.W., Washington, DC 20585

59. Kevin Adler, Hart Publications, Inc., 1925 N. Lynn Street, Suite 1000, Arlington, Virginia 22209

60. Mark A. Agee, Syntroleum Corporation, 400 S. Boston, Suite 1000, Tulsa, Oklahoma 74103

61. Subhash S. Aggarwal, Methanex Corporation, 1800 Waterfront Centre, 200 Burrard Street, Vancouver, British Columbia, Canada V6C 3M1 
62. Jeffrey Alson, AAATSD, USEPA National Vehicle and Fuel Emissions Laboratory, 2565 Plymouth Road, Ann Arbor, Michigan 48105

63. Ralph Avellanet, U.S. Department of Energy, FE-33, Room 3E-028, 1000 Independence Avenue, S.W., Washington, DC 20585

64. Michael Ball, Transport Canada, Canada Building, 344 Slater Street, Ottawa, Ontario, Canada K1A 0N5

65. Rich Bechtold, TA Engineering, Inc., Catonsville Professional Center, 405 Frederick Road, Suite 252, Baltimore, Maryland 21218

66. Andrew W. Bermingham, Montreux Energy Limited, International Energy Investment, 96 Kensington High Street, London W8 4SG, United Kingdom

67. Stephen S. Bernow, Tellus Institute, 11 Arlington Street, Boston, Massachusetts 021163411

68. Elizabeth Campbell, U.S. Department of Energy, PO-22, Room 7H-063, 1000 Independence Avenue, S.W., Washington, DC 20585

69. David Chien, U.S. Department of Energy, Energy Information Administration, EI-84, Room 2F-094, 1000 Independence Avenue, S.W., Washington, DC 20585

70. Barry Cohen, U.S. Department of Energy, Energy Information Administration, EI-81, Room 2F-095, 1000 Independence Avenue, S.W., Washington, DC 20585

71. Carol Dahl, Division of Economics and Business, Colorado School of Mines, Golden, Colorado 80401-1887

72. John DeCicco, American Council for an Energy-Efficient Economy, 1001 Connecticut Avenue, N.W., Suite 801, Washington, DC 20036

73. Mark A. Delucchi, 3925 Main Street, Fair Oaks, California 95628

74. Carmen Difiglio, International Energy Agency, 9 Rue de la Federation, Paris 75015, France

75. Jeff Dowd, U.S. Department of Energy, PO-22, Room 7H-075, 1000 Independence Avenue, S.W., Washington, DC 20585

76. K.G. Duleep, Energy and Environmental Analysis, Inc., 1655 North Fort Myer Drive, Suite 600, Arlington, Virginia 22209

77. Tracy E. Dunleavy, Eno Transportation Foundation, Inc., One Farragut Square South, 1634 I Street, N.W., Suite 500, Washington, DC 20006-4003

78. Jim J. Eberhardt, U.S. Department of Energy, EE-33, Room 5G-064, 1000 Independence Avenue, S.W., Washington, DC 20585

79. Ralph Erickson, U.S. Department of Transportation, Federal Highway Administration, 400 Seventh Street, S.W., HPM-10, Room 3306, Washington, DC 20590

80. Zhou Fenggi, Energy Research Institute of State Development Planning Commission of Chinese Academy of Sciences, Zhansimen, Shahe, Changping, Beijing 102206 China

81. Lew Fulton, International Energy Agency, 9 Rue de la Federation, Paris 75015, France

82. John Garbak, U.S. Department of Energy, EE-32, Room 5G-023, 1000 Independence Avenue, S.W., Washington, DC 20585

83. Dermot Gately, New York University, 70 Washington Square South, New York, NY 10012

84. Angela Georgiu, A. D. Little, 65 Yonge Street, Suite 400, Toronto, Ontario, Canada MSE $1 \mathrm{~J} 8$ 
85. Stephen Goguen, U.S. Department of Energy, EE-33, Room 5G-086, 1000 Independence Avenue, S.W., Washington, DC 20585

86. Howard Gruenspecht, U.S. Department of Energy, PO-21, Room 7H-034, 1000 Independence Avenue, S.W., Washington, DC 20585

87. Arthur Hartstein, U.S. Department of Energy, FE-33, Room G-134, 1000 Independence Avenue, S.W., Washington, DC 20585

88. David Hitchcock, Houston Advanced Research Center, Center for Global Studies, 4800 Research Forest Drive, The Woodlands, Texas 77381

89. James Kendell, U.S. Department of Energy, Energy Information Administration, EI-83, Room 2H-034, 1000 Independence Avenue, S.W., Washington, DC 20585

90. Wilfrid L. Kohl, The Johns Hopkins University, School of Advanced International Studies, 1619 Massachusetts Avenue, N.W., Washington, DC 20036

91. Damian Kulash, Eno Transportation Foundation, One Farragut Square South, 1634 I Street, N.W., Suite 500, Washington, DC 20006-4003

92. Andy S. Kydes, U.S. Department of Energy, Energy Information Administration, EI-80, Room 2F-081, 1000 Independence Avenue, S.W., Washington, DC 20585

93. David Kramer, McGraw-Hill, Inc., 1200 G Street, N.W., Suite 1100, Washington, DC 20005-3802

94. Skip Liatner, U.S. Environmental Protection Agency, Mail Code 6206J, 401 M Street, S.W., Washington, DC 20460

95. Lewison Lee Lem, U.S. Environmental Protection Agency, Energy and Transportation Sectors Division, Office of Policy, Mail Code 2126, 401 M Street, S.W., Washington, DC 20460

96. Thomas T. Leuchtenburg, Gas Research Institute, 1331 Pennsylvania Avenue, N.W., Suite 730 North, Washington, DC 20004-1703

97. John D. Maples, 2331 Putnam Lane, Crofton, MD 21114

98. Jim March, U.S. Department of Transportation, Federal Highway Administration, HPP-12, 400 Seventh Street, S.W., Washington, DC 20590

99. Jason Mark, Union of Concerned Scientists, 2397 Shattuck Avenue, Suite 203, Berkeley, California 94705

100. Paul McArdle, U.S. Department of Energy, EE-34, Room 034, 1000 Independence Avenue, S.W., Washington, DC 20585

101. Paula McGarrigle, Suncor Energy Inc., P.O. Box 38, $112-4^{\text {th }}$ Avenue, S.W., Calgary, Alberta, Canada T2P 2V5

102. Barry McNutt, U.S. Department of Energy, EP-50, Room 7H-021, 1000 Independence Avenue, S.W., Washington, DC 20585

103. James S. Moore, TA Engineering, Inc., 405 Frederick Road, Suite 252, Baltimore, Maryland 21228

104. Bob Nimocks, Zeus Development Corporation, 2424 Wilcrest Drive, Suite 250, Houston, Texas 77042

105. Tien Nguyen, U.S. Department of Energy, EE-31, Room 1J-105, 1000 Independence Avenue, S.W., Washington, DC 20585 
106. Philip D. Patterson, U.S. Department of Energy, EE-30, Room 5F-034, 1000 Independence Avenue, S.W., Washington, DC 20585

107. William S. Pintz, East-West Center, 1777 East-West Road, Honolulu, Hawaii 96848

108. Steve Plotkin, Argonne National Laboratory, 955 L’Enfant Plaza, S.W., Suite 6000, Washington, DC 20024

109. Peter Reilly-Roe, Energy, Mines and Resources Canada, Transportation Energy Use Division, 580 Booth Street, $12^{\text {th }}$ Floor, Ottawa, Ontario, Canada K1A 0E4

110. David Rodgers, U.S. Department of Energy, EE-34, Room 5G-086, 1000 Independence Avenue, S.W., Washington, DC 20585

111. Art Rosenfeld, U.S. Department of Energy, EE-40, Room 5E-052, 1000 Independence Avenue, S.W., Washington, DC 20585

112. Mamdouh G. Salameh, Oil Market Consultancy Service, Spring Croft, Sturt Avenue, Haslemere, Surrey, GU27 3SJ, England

113. Danilo J. Santini, Argonne National Laboratory, 9700 South Cass Avenue, Argonne, Illinois 60439

114. Vincent D. Schaper, NREL, 409 12th Street, Suite 710, Washington, DC 20024-2125

115. Robert N. Schock, University of California, Lawrence Livermore National Laboratory, 7000 East Avenue, Livermore, California 94550-9234

116. Margaret Singh, Argonne National Laboratory, 955 L’Enfant Plaza, S.W., Suite 6000, Washington, DC 20024

117. Dan Sperling, International Energy Agency, 9 Rue de la Federation, Paris 75015, France

118. Shane Streiffel, The World Bank, 1818 H Street, N.W., Washington, DC 20433

119. Thomas W. Thompson, Northeast Sustainable Energy Association, 50 Miles Street, Greenfield, Massachusetts 01301

120. Michael A. Toman, Resources for the Future, 1616 P Street, N.W., Washington, DC 20036

121. Donald R. Trilling, U.S. Department of Transportation, Office of the Secretary, 400 Seventh Street, S.W., Room 9222, Washington, DC 20590

122. Harry Vidas, Energy and Environmental Analysis, Inc., 1655 North Fort Myer Drive, Suite 600, Arlington, Virginia 22209

123. Michael P. Walsh, 3015 N. Dinwiddie Street, Arlington, Virginia 22207

124. Michael Q. Wang, Argonne National Laboratory, 9700 South Cass Avenue, Argonne, Illinois 60439

125. Larry Weick, Syntroleum Corporation, 1350 South Boulder, Suite 1100, Tulsa, Oklahoma 74119-3295

126. James Zucchetto, Board on Energy and Environmental Systems, National Academy of Sciences, National Academy of Engineering, 2101 Constitution Avenue, N.W., Washington, DC 20418

127. Kurt D. Zwally, U.S. Department of Energy, Office of Energy Efficiency \& Renewable Energy, 1000 Independence Avenue, W.W., EE-30, Washington, DC 20585

128. John Zyren, U.S. Department of Energy, Energy Information Administration, 1000 Independence Avenue, S.W., Washington, DC 20585 
